IZA DP No. 7378

Intra-Firm Upward Mobility and Immigration

Mohsen Javdani

Andrew McGee

April 2013

Forschungsinstitut zur Zukunft der Arbeit Institute for the Study of Labor 


\title{
Intra-Firm Upward Mobility and Immigration
}

\author{
Mohsen Javdani \\ University of British Columbia, Okanagan \\ Andrew McGee \\ Simon Fraser University \\ and IZA
}

Discussion Paper No. 7378

April 2013

IZA

P.O. Box 7240

53072 Bonn

Germany

Phone: +49-228-3894-0

Fax: +49-228-3894-180

E-mail: iza@iza.org

Any opinions expressed here are those of the author(s) and not those of IZA. Research published in this series may include views on policy, but the institute itself takes no institutional policy positions. The IZA research network is committed to the IZA Guiding Principles of Research Integrity.

The Institute for the Study of Labor (IZA) in Bonn is a local and virtual international research center and a place of communication between science, politics and business. IZA is an independent nonprofit organization supported by Deutsche Post Foundation. The center is associated with the University of Bonn and offers a stimulating research environment through its international network, workshops and conferences, data service, project support, research visits and doctoral program. IZA engages in (i) original and internationally competitive research in all fields of labor economics, (ii) development of policy concepts, and (iii) dissemination of research results and concepts to the interested public.

IZA Discussion Papers often represent preliminary work and are circulated to encourage discussion. Citation of such a paper should account for its provisional character. A revised version may be available directly from the author. 


\section{ABSTRACT}

\section{Intra-Firm Upward Mobility and Immigration ${ }^{*}$}

We examine how immigrants in Canada fare in terms of promotions relative to their native peers. Using linked employer-employee data and firm effects, we identify the extent to which differences in promotion outcomes result from immigrants sorting into firms offering "deadend" jobs versus facing intra-firm barriers to advancement. We find that while white immigrants experience broadly similar promotion outcomes relative to their white native peers, visible minority immigrants - particularly those in their first five years in Canada - are substantially less likely to have been promoted and have been promoted fewer times with their employers than their white native peers. Newly arrived female visible minority immigrants sort into firms offering "dead end" jobs, but most of the differences in promotion outcomes between immigrants and their native peers result from intra-firm differences in promotion outcomes. The findings imply that policies that do not tackle barriers to advancement within firms may be insufficient to address the difficulties faced by immigrants in the labor force.

JEL Classification: J61, J71

Keywords: promotions, immigration

Corresponding author:

Andrew McGee

Department of Economics

Simon Fraser University

8888 University Drive

Burnaby, BC V5A 156

Canada

E-mail: amcgee@sfu.ca

\footnotetext{
* We thank participants at the 2012 meetings of the Canadian Economics Association and the Society of Labor Economics and the SWUFE International Workshop on Applied Microeconomics for useful comments and discussion.
} 


\section{Introduction}

The comparative labor market performance of immigrants and natives and the extent to which immigrants are successful in adjusting to their new labor market conditions are important components in debates concerning optimal immigration policies. Most prior studies of the labor market performance of immigrants consider either wages or hiring decisions (e.g., Borjas 1993, Baker and Benjamin 1994, Green 1999, Friedberg 2000, Aydemir 2003, Ferrer and Riddell 2008, Green and Worswick 2012). Promotion outcomes, however, are one of the primary drivers of improvements in income and social status for all workers-including immigrants. Strong evidence suggests that promotions are associated with large wage increases (e.g., Milkovich 1989, Lazear 1992). McCue (1996) estimates that promotions explain as much as $15 \%$ of wage growth over the life cycle. ${ }^{1}$ Promotions are particularly pertinent outcomes when examining whether the labor market experiences of immigrants and natives differ as promotion decisions in many workplaces are subject to less scrutiny than hiring decisions because of the subjective nature of the promotion process-making discrimination difficult to detect. This study contributes to the existing literature concerning differences in the labor market experiences of natives and immigrants by examining differences in promotion outcomes. To our knowledge, this is the first study to investigate differences in intra-firm upward mobility between immigrants and their native peers.

Economists have long documented that newly arrived immigrants earn less than natives (e.g., Chiswick 1978, Bloom and Gunderson 1991). More recent studies find that more recent cohorts of immigrants experience a larger initial earnings disadvantage relative to natives and do less "catching up" to natives in terms of earnings than earlier cohorts of immigrants (Borjas

\footnotetext{
${ }^{1}$ Baker et al. (1994) find evidence that workers who receive large wage increases early in their stay at one level of the job ladder are promoted more quickly to the next. This is consistent with McCue's (1996) finding of a positive relationship between high wages today and the likelihood of promotions tomorrow.
} 
1994, Baker and Benjamin 1994, Bloom et al. 1995, Waslander 2003). More recent immigrants may do less "catching up" with natives if they experience slower earnings growth by virtue of failing to keep pace with their native counterparts in "climbing the corporate ladder."

Immigrants may be less likely to be promoted than natives with the same observed characteristics if they enjoy lower returns in Canada to their foreign education or foreign work experience, lack unobserved skills required to perform at higher levels within a firm (e.g., language skills), lack the social networks required to facilitate promotions, or if firms have a preference for promoting natives and engage in discrimination. These mechanisms could lead to differences in promotion opportunities between observationally equivalent natives and immigrants within the same workplace or to the disproportionate sorting of immigrants into firms offering fewer promotion opportunities—firms hiring workers into "dead-end" jobs—-just as Aydemir and Skuterud (2008) and Pendakur and Woodcock (2010) find that immigrants to Canada sort into firms offering lower average wages.

Investigating the extent to which economy-wide differences in promotion opportunities operate between firms versus within firms requires information on the promotion outcomes of multiple workers within the same firm across many firms. To this end, we employ the Workplace and Employee Survey (WES) collected by Statistics Canada, a representative sample of employees and their employers in Canada with information concerning the promotion histories of multiple workers from each firm. A cursory inspection of our sample suggests that immigrants sort non-randomly into different firms than their native peers. Figure 1 plots the distributions of immigrants and natives by the percentage of sampled workers at their employers who are immigrants. Consistent with studies of immigrant enclaves in the workplace (e.g., Wilson and 
Portes 1980, Hellerstein and Neumark 2008, Sousa 2011), immigrants are employed in firms with significantly higher concentrations of immigrants than their native peers.

Evidence of immigrant enclaves in the workplace, however, does not necessarily imply that this sorting results in differences in advancement opportunities. Figure 2 plots the fraction of workers who have ever been promoted with the employer by the percentage of their employer's sampled workers who are immigrants. The fraction of workers who have ever been promoted is significantly lower in firms whose sampled workforces consist of more than $90 \%$ immigrants (27.4\%) than in firms in which immigrants make up less than half of the sampled workforce (3545\%). Whether a worker has ever been promoted may mask differences in promotion experiences if some workers are promoted more frequently than others. Figure 3 plots the average number of promotions with the employer for workers by the percentage of their employer's sampled workers who are immigrants. Similar to figure 2, the average number of promotions declines significantly in firms whose sampled workers are predominantly immigrants. Taken together, Figures 1, 2 and 3 provide suggestive but unconditional evidence that (a) immigrants sort non-randomly across firms and (b) that workers at firms with more immigrants experience fewer promotions. ${ }^{2}$

We examine differences in promotion outcomes between natives and immigrants and the extent to which these differences are driven by disproportionate sorting of immigrants into firms with fewer promotion opportunities versus differences in promotion outcomes within firms relative to natives. Specifically, we estimate models of the probability of having ever been promoted and the number of times a worker has been promoted while working for his/her current employer controlling for membership in a minority group (visible minority Canadians, white immigrants, and visible minority immigrants) and individual and job characteristics with and

\footnotetext{
${ }^{2}$ Warman (2007) finds that residential enclaves are negatively related to immigrants' wages in Canada.
} 
without firm effects. We then compare the estimated within-firm differences in promotion outcomes to the estimated economy-wide differences to identify the extent to which differences result from intra-firm differences in advancement between immigrants and natives or the sorting of immigrants into firms offering “dead-end” jobs.

Economy-wide, we find that male (female) visible minority immigrants are 4.7 (7.6) percentage points less likely to have been promoted while working for their current employer than their observationally equivalent white native peers, while white immigrants are not significantly less likely to have been promoted than their native peers. For comparison, Pergamit and Veum (1999) find that women, blacks, and Hispanics in the 1979 National Longitudinal Study of Youth were 4, 5, and 6 percentage points less likely to be promoted than their white peers. Similarly, we find that male (female) visible minority immigrants have been promoted an estimated $0.22(0.20)$ fewer times than their observationally equivalent white native peers with their current employers; white male immigrants have been promoted an estimated 0.09 fewer times than their native peers.

Among visible minority immigrants, there is significant heterogeneity in promotion outcomes based on the number of years immigrants have been in Canada. Female visible minority immigrants in their first five years in Canada are an estimated 14.6 percentage points less likely to have been promoted and have been promoted an estimated 0.33 fewer times with their current employers than observationally equivalent white natives, and significant fractions of these differences result from being employed in firms with fewer advancement prospects. ${ }^{3}$ Such sorting, however, does not appear to be significant among most other immigrants. Female visible minority immigrants with more time in Canada close the gaps in promotion probabilities and

\footnotetext{
${ }^{3}$ These estimates account for differences in tenure with the current employer between natives and immigrants. As reported in our tables, estimates of the differences in promotion outcomes without controlling for tenure are significantly larger in magnitude.
} 
number of times promoted, but significant differences in promotion outcomes are still evident among female visible minority immigrants who have been in Canada for over twenty years. Male visible minority immigrants in their first five years in Canada are no less likely to have been promoted but have been promoted an estimated 0.19 fewer times than their native white peers in their first five years in Canada, and this difference stems entirely from intra-firm differences in promotion outcomes rather than sorting across firms. Otherwise, we observe differences between male visible minority immigrants and comparable white natives only among immigrants who have been in Canada for more than 20 years. Male visible minority immigrants who have been in Canada for more than 20 years are an estimated 10.1 percentage points less likely to have been promoted and have been promoted an estimated 0.34 fewer times with their current employers than their native white peers-differences that stem in part from their employment in firms offering fewer advancement opportunities.

In addition to investigating heterogeneity in immigrants' promotion experiences based on years since immigration, we consider whether immigrants' promotion experiences depend on their skill levels. Oreopolous (2011) finds in a field experiment that the resumes of skilled immigrants are less likely to generate interest from potential employers than those of comparable natives. If skilled immigrants have a hard time getting "their foot in the door," they may have similar difficulty advancing. Further, skilled and unskilled immigrants potentially operate in very different labor markets. Skilled immigrants may face more significant barriers to advancement than less skilled immigrants if, for instance, human capital becomes more important for advancement on skilled jobs than for less skilled jobs and the human capital of immigrants is discounted. Alternatively, skilled immigrants may begin their careers in Canada in jobs for 
which they are overqualified in some unobserved sense and advance more rapidly than their less skilled counterparts as a result.

To investigate whether the labor markets for skilled and unskilled immigrants result in different promotion experiences, we estimate our models of promotion probabilities and the number of promotions received fully interacted with an indicator for whether the worker has a bachelor's degree or higher. We find that female visible minority immigrants without a bachelor's degree are much less likely to have been promoted and have been promoted fewer times than observationally equivalent white natives, but female visible minority immigrants with a bachelor's degree are for the most part just as likely to have been promoted and have been promoted the same number of times as their white native counterparts. Among male immigrants, on the other hand, we find few differences across educational groups.

In our data, the first promotion a worker receives with the current employer is associated with estimated wage increases of $6.8 \%$ and $6.4 \%$ for women and men, respectively. While we do not estimate the differences in wages that result from differences in promotion experiences, our findings suggest that that intra-firm differences in promotion experiences between natives and immigrants_-primarily visible minority immigrants who have been in Canada for less than five years or more than 20 years-may be a source of wage differences between these groups. ${ }^{4}$ These findings have important policy implications for antidiscrimination policies in the labor market. Antidiscrimination policies focus on the hiring decision and on pay equity at given levels within firms. Employment equity policies promoting equal employment opportunities at firms for all workers, however, do not address a mechanism through which immigrants may fall behind in terms of wages: the failure to keep pace with their native peers in climbing the corporate ladder

\footnotetext{
${ }^{4}$ Olson and Becker (1983) find that the difference in promotion rates explains a significant fraction of the malefemale wage differential in the United States.
} 
within firms once they have their "foot in the door." Similarly, pay equity policies do little to benefit immigrants if immigrants—even while earning equal pay for equal work—are less able to move up the ladder to more demanding — and higher paying — jobs. We find that visible minority immigrants are indeed less likely to be promoted and are promoted fewer times than their native peers, and these differences in promotion outcomes primarily result from within-firm differences in advancement experiences. Existing antidiscrimination policies will be insufficient if these promotion outcome differentials are the result of discrimination. If discrimination is to blame for the adverse promotion experiences of immigrants and visible minorities more generally, then antidiscrimination policies must ensure that such workers face a level playing field within firms when competing for promotions.

\section{Data}

Our study uses the Workplace and Employee Survey (WES), a longitudinal survey of employers and their employees collected by Statistics Canada between 1999 and 2006—one of only a few linked employer-employee databases worldwide and the only such data in Canada. In every year, a representative sample of approximately 6,000 employers was surveyed. The target population of employers consisted of all business locations in Canada with paid employees in March of each surveyed year. ${ }^{5}$ In the 1999, 2001, 2003, and 2005 surveys, the sample of employers was refreshed with new employers from the Statistics Canada Business Register to maintain a representative cross-section. A maximum of twenty-four employees were interviewed from each sampled firm in each odd year and re-interviewed the following year. ${ }^{6}$ Our analysis is based on

\footnotetext{
${ }^{5}$ Employers in the Yukon, Nunavut and Northwest Territories and employers operating in crop production, animal production, fishing, hunting, trapping, private households, religious organizations and public administration were excluded from the sample. Public administration includes establishments primarily engaged in the enactment and judicial interpretation of laws and their pursuant regulations and the administration of programs based on them. Public administration's share of employment in Canada is around 6.5 percent (Statistics Canada, Table 281-0024).

${ }^{6}$ The number of workers interviewed from each firm was proportional to firm's size except for workplaces with fewer than four employees in which all employees were surveyed.
} 
the pooled 1999, 2001, 2003 and 2005 cross-sections. Following other studies using the WES, data from interviews in the even-numbered years are not used to avoid the sample selection problems associated with employee attrition.

We restrict the sample to non-Aboriginal workers between the ages of 24 and 65 from firms that have at least two male or female workers sampled over the entire period they appear in the data. The restricted sample includes 32,403 women and 42,467 men from 7,531 firms. We observe between two and 63 employees from each firm; the mean (median) number is 12 (10). We observe 2,577 firms in all four years, 1,674 firms in three years, 1,609 firms in two years and the remaining 1,671 firms in a single year.

The dependent variables in our study are an indicator for whether the employee has ever been promoted while working for the current employer and the number of times the employee has been promoted with the current employer. The indicator for whether the employee has ever been promoted comes from his/her response to the question, "Have you ever been promoted while working for this employer? (By promotion we mean a change in duties/responsibilities that led to both an increase in pay and the complexity or responsibility of the job.)”"7

Table 1 details the summary statistics for our sample. Differences among white and visible minority immigrants are especially evident when we examine promotion outcomes. Only $33.9 \%$ (28.8\%) of male (female) visible minority immigrants have ever been promoted with their current employers relative to $40.9 \%$ (34.2\%) of male (female) white immigrants, who are only slightly less likely to have been promoted than their white native peers. Further, male (female) visible minority immigrants have been promoted only $0.64(0.47)$ times on average relative to $1.00(0.71)$ times for white male (female) Canadian-born workers and $0.88(0.70)$ times for white male (female) immigrants. Visible minority Canadian-borns fare better than visible minority

\footnotetext{
${ }^{7}$ Changes in pay and responsibilities are two distinguishing features of promotions (Pergamit and Veum 1999).
} 
immigrants in terms of the probability of promotion and number of times promoted but are less likely to have been promoted and have received fewer promotions than both white immigrants and white natives.

These unconditional differences in promotion outcomes suggest that the promotion experiences of visible minority immigrants differ substantially from their Canadian-born peers and other immigrants. Immigrants and Canadian-born workers, however, differ in a number of observable characteristics — differences which might account for the observed differences in promotion outcomes. Male and female visible minority immigrants have less labor market experience on average than their white peers (immigrants and non-immigrants), but immigrants of both genders and all races are more likely to have completed a post-secondary degree than their Canadian-born peers. Visible minority immigrants are much younger on average than white immigrants and have been in Canada for shorter periods. Immigrants are much more likely to speak a language other than English or French at home than their native peers. Furthermore, all immigrants are much more likely to be married and to have larger families than natives. Immigrants of all stripes are much less likely to move to Quebec — moving instead to Ontarioand much more likely to live in Census Metropolitan Areas than Canadian-born workers. Perhaps most important for our purposes, immigrants have considerably shorter average tenures with their current employers than native workers. This is mechanical for newly arrived immigrants: an immigrant who has been in Canada for less than five years cannot have been with his current employer for more than five years. Workers who have been with their firms longer have necessarily had more opportunities to be considered for promotion, so this difference between immigrants and natives is potentially significant in the empirical analysis. 
In total, 9.8\% of observations come from male immigrants, while $7.9 \%$ of observations come from female immigrants. We create indicators for being a Canadian-born visible minority, a white immigrant, or a visible minority immigrant, with white Canadian-born workers serving as the reference category. In some specifications we further break the immigrants into four additional categories based on their years since arriving in Canada ( 0 to 5 years, 6 to 10 years, 11 to 20 years, and 21 or more years in Canada) to account for assimilation and differences among immigrant cohorts. We additionally control for the employee's highest level of schooling (8 categories), marital status (6 categories), number of dependent children (5 categories), a quartic in years of (actual) full-time labor market experience, full-time employment, age (8 categories), languages spoken at home and at work, province of residence, residence in a Census Metropolitan Area, membership in a union or collective bargaining agreement, and-in some specifications - a quadratic function of the worker's tenure with her employer. In robustness checks, we also control for the employee's occupation (6 categories) and industry (14 categories). We estimate all specifications using employee sample weights provided by Statistics Canada, and the standard errors are estimated following Statistics Canada's recommended procedure using 100 sets of bootstrap sample weights. ${ }^{8}$

\section{Empirical Methodology}

The probability that an employee has ever been promoted with his/her current employer is of special interest given that the first promotions received by workers with their current employers in our data are associated with larger wage increases than subsequent promotions. Estimating whether a worker has ever been promoted, however, may obscure differences in the advancement experiences of immigrants and other minority groups if workers in these groups are

\footnotetext{
${ }^{8}$ The bootstrap weights take into account the potential non-independence of error terms for workers within the same firm and adjust for variation due to the two-stage sampling of employees as well as the complex survey design of the WES (Drolet 2002).
} 
promoted more or less frequently with their current employers than their white Canadian-born peers. Immigrants may succeed in obtaining early promotions-particularly pro forma promotions — while still falling behind their Canadian-born peers if these peers enjoy subsequent promotions that immigrants do not. As such, we estimate models of both whether a worker has ever been promoted with his/her current employer and the number of times the worker has been promoted with the current employer.

We estimate differences in average promotion outcomes between white natives and different groups of immigrants conditional on observed individual and job characteristics using the linear regression model:

$$
E\left[P_{i} \mid X_{i}, g_{i}\right]=X_{i}^{\prime} \beta+g_{i}^{\prime} \delta,
$$

where $P_{i}$ is—depending on the regression—either an indicator for having ever been promoted with the current employer or the number of times promoted while working for the current employer, $X_{i}$ a vector of individual and job characteristics, and $g_{i}$ a vector of indicators for membership in a minority group (i.e., white immigrants, visible minority Canadian-borns, and visible minority immigrants). ${ }^{9}$ The parameter vector $\beta$ captures the relationships between observed characteristics and promotion outcomes, while $\delta$ measures the economy-wide differences in average promotion outcomes between workers in different minority groups and white Canadian-born workers conditional on $X_{i}$.

To measure the extent to which the economy-wide differences in average promotion outcomes between white natives and immigrants are driven by immigrants sorting into firms

\footnotetext{
${ }^{9}$ When $P_{i}$ is an indicator for having ever been promoted with the current employer, this is a linear probability model. We also estimated the economy-wide differences in the probability of promotion between immigrants and natives using probit and logit estimators; estimates from these models were similar to those reported in tables 2a and 2b. We use the linear probability model for the ease of incorporating firm effects. Likewise, we estimated models of the number of times promoted using a Poisson estimator and obtained similar results to those in tables 3a and 3b.
} 
with fewer promotion opportunities, we estimate the within-firm native-immigrant differences in average promotion outcomes by adding firm effects to (1):

$$
E\left[P_{i} \mid X_{i}, g_{i}, f_{i}\right]=X_{i}^{\prime} \beta+g_{i}^{\prime} \delta+f_{i}^{\prime} \psi,
$$

where $f_{i}$ is a vector of indicators for each firm. The vector $\psi$ captures the firm effects representing inter-firm differences in average promotion outcomes conditional on worker and job characteristics $X_{i}$ and group membership $g_{i}$.

Estimates of the economy-wide differences in average promotion outcomes between natives and immigrants in equation (1), $\hat{\delta}$, capture (a) any systematic sorting of minorities into firms offering fewer opportunities for advancement, (b) the correlation between minority group membership and unobserved worker characteristics related to promotion outcomes and (c) firms' preferences for promoting white Canadian-born workers relative to other workers. In contrast, the estimates of $\delta$ in equation (2), $\tilde{\delta}$, measure conditional native-immigrant differences in average promotion outcomes within firms. If $\hat{\delta}<0$ for group $g$, then members of this group are less likely to have been promoted or have been promoted fewer times on average than their white Canadian-born peers. If $0 \geq \tilde{\delta}>\hat{\delta}$, then workers in this group systematically sort into jobs at firms with fewer opportunities for advancement. If $0>\tilde{\delta}=\hat{\delta}$, then we infer that the average difference in promotion outcomes for workers in this group relative to white Canadian-born workers results entirely from differences in advancement within firms rather than systematic sorting of workers to firms with different advancement opportunities. We use a Hausman test to test the null hypothesis that $\hat{\delta}-\tilde{\delta}=0$ (i.e., that there is no systematic sorting of immigrants into firms offering different opportunities for advancement). ${ }^{10}$

\footnotetext{
${ }^{10}$ Under the null hypothesis of no differences between immigrants and natives in sorting across firms, both specifications produce consistent estimates of the promotion gap, $\delta$, but the estimates in the specification with firm effects are inefficient. Under the alternative hypothesis of systematic native-immigrant inter-firm sorting, only the
} 
When estimating immigrant-native promotion outcome differentials, we face an important specification decision: whether to include tenure with the current employer as a control. Promotion outcomes and tenure are potentially simultaneously determined as whether one has advanced with one's employer likely influences the decision to remain with the employer while employees with longer tenures have necessarily had more opportunities for promotion. Omitting tenure from the controls introduces a downward bias in our estimates of the native-immigrant promotion outcome differentials if tenure is positively related to promotion outcomes - as it is in our data-and immigrants on average have shorter tenures with their employers than natives. ${ }^{11}$ As table 1 indicates, visible minority immigrants-especially newly arrived immigrants-have considerably shorter average tenures with their current employers than native workers in large part because an immigrant's potential tenure with an employer is bounded above by the number of years an immigrant has been in Canada.

Including tenure as a control, on the other hand, introduces a simultaneity bias when estimating the immigrant-native promotion outcomes differentials. Specifically, if there are differences between immigrants and natives in the unobserved factors that affect promotion outcomes and if these differences are correlated with tenure, then there will exist a simultaneity bias when estimating the immigrant-native promotion outcomes differentials that cannot be signed a priori.

To assess the importance of the simultaneity bias, we look for minority groups who have comparable tenure to white Canadian-born workers. If minority group $g$ and white Canadianborn workers have comparable tenure, then there will be no omitted variables bias in our

estimates from the specification with firm effects are consistent. Pendakur and Woodcock (2010) and Javdani (2012) use similar tests for sorting in studies of immigrant-native and male-female wage differences.

11 MacDonald and Worswick (1998) evaluate the bias when tenure is omitted when estimating native-immigrant wage differentials in Canada. 
estimates of the immigrant-native promotion outcome differential when we omit tenure as a control. In this case, the difference between our estimators with and without tenure reflects the simultaneity bias, which allows us to assess the empirical importance of the simultaneity bias with tenure included as a control. The simultaneity bias may be trivial if tenure is uncorrelated or only weakly correlated with the unobserved differences between natives and immigrants that affect promotion outcomes. In light of the potential omitted variables and simultaneity biases, we estimate the immigrant-native promotion outcome differentials both with and without tenure as a control in the next section.

Finally, we consider whether university-educated immigrants compete for promotions in different labor markets than less educated immigrants and experience different promotion outcome differentials relative to their white Canadian-born peers as a result. To do so, we estimate (1) and (2) interacting all regressors (except firm effects) with an indicator for education greater than a bachelor's degree.

\section{Findings}

\section{IV.A Immigration and the Probability of Promotion}

Table 2a presents the estimated differences in the probability of having ever been promoted with the current employer for minority groups relative to white natives for women controlling for individual and job characteristics and region of residence; Appendix table 1 illustrates that our estimates are robust to including controls for the worker's industry and occupation. The top panel of table 2a presents estimates for visible minority Canadian-born workers, white immigrants, and visible minority immigrants relative to white Canadian-born workers. Columns 1 and 2 report estimates of the economy-wide and within-firm promotion differentials ( $\delta$ in 
equations (1) and (2), respectively) without tenure as a control, while columns 4 and 5 report these estimates with tenure included.

Regardless of whether we include tenure as a control, we find little evidence that female white immigrants are less likely to be promoted than their white Canadian-born peers. Female visible minorities, however, are significantly less likely to have been promoted with their current employers: a female visible minority Canadian-born (immigrant) worker is 8.5 (9.5) percentage points less likely to have been promoted with the current employer than an observationally equivalent white Canadian-born worker when tenure is not included as control and 8.7 (7.6) percentage points less likely to have been promoted when tenure is included. With and without tenure as a control, we find statistically significant evidence that female visible minority immigrants sort into firms in which they are less likely to be promoted-firms offering "deadend” jobs—-when comparing the economy-wide estimates in columns 1 and 4 to the within-firm estimates in columns 2 and 5. For these women, differential sorting explains 31 percent and 41 percent of the economy-wide promotion gaps in the specifications without and with tenure, respectively.

The top panel of table $2 \mathrm{~b}$ reports the same estimates for men. Again, both native and immigrant visible minorities_-but not white immigrants — are less likely to have been promoted regardless of whether we control for tenure. A male visible minority Canadian-born (immigrant) worker is $8.4(6.0)$ percentage points less likely to have been promoted with the current employer than an observationally equivalent white Canadian-born worker when tenure is not included as control, and 8.0 (4.7) percentage points less likely to have been promoted when tenure is included as a control. In contrast to their female counterparts, we find no evidence of systematic sorting into firms offering fewer promotion opportunities among male visible minority 
immigrants, implying that the economy-wide difference in the probability of promotion is driven by worse promotion outcomes within firms compared to their white native counterparts.

The estimates in columns 1 and 2 for immigrants in the top panels of tables $2 \mathrm{a}$ and $2 \mathrm{~b}$ likely suffer from an omitted variables bias as immigrants have considerably shorter average tenures with their current employers. The estimates in columns 4 and 5, on the other hand, potentially suffer from a simultaneity bias as tenure is jointly determined with promotion outcomes. To assess the omitted variables and simultaneity biases and to explore heterogeneity in promotion outcomes among immigrants, we examine differences in the estimated promotion probability gaps for immigrants who have been in Canada for various periods relative to their white Canadian-born peers with and without controls for tenure in the bottom panels of tables 2a and $2 \mathrm{~b}$.

The importance of the omitted variables bias when tenure is omitted is especially evident among newly arrived immigrants. Female visible minority immigrants who have been in Canada for less than six years are 21.4 percentage points less likely to have been promoted with their current employer when tenure is omitted, but only 14.6 percentage points less likely to have been promoted when tenure is included as a control, meaning that omitting tenure accounts for $32 \%$ of the estimated promotion outcome differential in column 1 . Similarly white female immigrants who have been in Canada for less than six years are 8.6 percentage points less likely to have been promoted without controlling for tenure, but this gap essentially disappears when tenure is included as a control.

For men, controlling for tenure is even more important: a male visible minority immigrant who has been in Canada for less than six years is an estimated 14.4 percentage points less likely to have been promoted with his current employer when tenure is omitted, but only a 
statistically insignificant 3.3 percentage points less likely to have been promoted when tenure is included. The importance of the omitted variable bias among newly arrived immigrants is hardly surprising given that in table 1 we see that newly arrived male and female visible minority immigrants have on average only 1.9 and 2.2 years of tenure; white Canadian-born workers have considerably longer tenures with their employers even after controlling for age and work experience. Ignoring tenure greatly overstates the differences between immigrants in their first years in Canada and observationally equivalent white Canadian-born workers in terms of the probability of promotion.

By contrast, the simultaneity bias when we control for tenure in column 4 appears to be of limited empirical importance. Immigrants who have been in Canada for more than 20 yearspresumably most of their working lives—are much less likely to be systematically different from their native peers in terms of tenure as relatively few workers have been with their employers for more than 20 years; this is indeed what we observe in table 1. As such, we assume that the omitted variables bias in column 1 is small or non-existent for immigrants who have been in Canada for more than 20 years and that the difference between the estimates in columns 1 and 4 for such workers reflects the extent of the simultaneity bias. For both males and females, the differences between these estimates are small, and what differences we observe are consistent with the small differences in tenure between immigrants who have been in Canada for more than 20 years and white Canadian-born workers that we observe in table $1 .{ }^{12}$ Similar comparisons of the estimates in columns 1 and 4 for visible minority Canadian-born workers who have comparable tenures with their employers once we control for age and experience also suggest

\footnotetext{
${ }^{12}$ The estimated economy-wide difference in promotion probabilities for visible minority males who have been in Canada for more than 20 years relate to white natives with tenure included as a control in column 4 is 20 percent larger than the corresponding estimate without tenure included as a control, but we fail to reject equality of the two estimates. We similarly fail to reject equality of the estimates with and without tenure for all other immigrants of both genders who have been in Canada for more than 20 years.
} 
that the simultaneity bias is small. ${ }^{13}$ We infer that the simultaneity bias is of limited empirical importance and focus on the estimates in columns 4 and 5 for all immigrants in the following discussion. ${ }^{14}$

Contrary to what we might conclude from the upper panels, the differences in promotion probabilities between immigrants and their native peers that we observe in columns 4 and 5 in the lower panels of tables $2 \mathrm{a}$ and $2 \mathrm{~b}$ are few. For white female immigrants, the estimated differences in the probability of promotion relative to white natives in table 2a are statistically indistinguishable from zero regardless of how long an immigrant has been in Canada. A female visible minority immigrant who has been in Canada for less than five years, however, is an estimated 14.6 percentage points less likely to have been promoted with her current employer than an observationally equivalent white Canadian-born worker. Furthermore, half of this estimated promotion probability differential stems from newly arrived female visible minority immigrants being employed in firms in which there is a lower probability of promotion. After the first five years in Canada, however, this sorting does not affect the promotion probabilities of female visible minority immigrants. Female visible minority immigrants who have been in Canada for between six and twenty years are only three percentage points less likely to have been promoted-though these estimated promotion differentials are not statistically significant. Female visible minority immigrants who have been in Canada for more than 20 years, however, are a statistically significant 7.2 percentage points less likely to have ever been promoted with her current employer than a white native worker.

\footnotetext{
13 The considerably shorter average tenure of visible minority Canadian-born workers in table 1 relative to white Canadian-born workers reflects the fact that visible minority Canadian-born workers in our sample are on average much younger and have been in the labor force for shorter periods than their white peers.

${ }^{14}$ Other studies of promotion outcomes (e.g., Pergamit and Veum 1999, Hersch and Viscusi 1996) also ignore the potential simultaneity of tenure and promotion outcomes.
} 
Among male immigrants, we find no evidence that either white or visible minority immigrants are less likely to have been promoted than their white native peers except for visible minority immigrants who have been in Canada for more than 20 years who are an estimated 10.1 percentage points less likely to have been promoted—part of which results from such men being employed in firms offering fewer advancement opportunities. Indeed, if anything, white immigrants in their first ten years in Canada are more likely to have been promoted than their white native peers. The reappearance of the "promotion gap" among male and female visible minority immigrants who have been in Canada for more than 20 years is consistent with these immigrants encountering a "glass ceiling” blocking their further ascent up the job ladder. ${ }^{15}$ This could be due to mechanisms that prevent immigrants from fully assimilating into the labor market such as discrimination or smaller social networks, but it could also be driven by changes in the "quality" of immigrant cohorts in terms of their unobservable attributes that might result from changes in immigration policies (Chiswick 1978; Borjas 1985). Because we use pooled cross-sections over just a six year period, we are unable to distinguish between these two scenarios.

\section{IV.B Immigration and the Number of Promotions Received}

While we observe differences in promotion probabilities relative to white natives only for some groups of immigrants, these estimates might obscure differences in promotion experiences if immigrants are promoted less often than their white native peers. Tables $3 \mathrm{a}$ and $3 \mathrm{~b}$ report the estimated differences in number of promotions received with the current employer for minority groups relative to white Canadian-born workers for female and male workers, respectively. A female (male) visible minority immigrant has received an estimated 0.202 (0.221) fewer

\footnotetext{
${ }^{15}$ Examining wage differentials between natives and immigrants in Canada, Pendakur and Woodcock (2011) find evidence consistent with immigrants facing a "glass ceiling." Specifically, they find that visible minority immigrants are under-represented at the top of the wage distribution conditional on their characteristics.
} 
promotions with the current employer than an observationally equivalent white Canadian-born worker when tenure is included as control. Among visible minority Canadian-born workers and white immigrants, we find that men in these groups have been promoted fewer times than their white native peers but no such evidence for women. We find evidence of systematic sorting into firms that promote workers less often only among male visible minority immigrants.

Again we compare the estimates in column 1 to those in column 4 in the bottom panels of tables 3a and $3 \mathrm{~b}$ to assess the importance of the omitted variables bias in the estimates in column 1 when tenure is omitted and the simultaneity bias in the estimates in column 4 when tenure is included as a control. The omitted variables bias when tenure is omitted is potentially more significant in models of the number of promotions relative to models of the probability of promotion as in spite of shorter tenures newly arrived immigrants may have been with the employer long enough to obtain a first, potentially pro forma promotion but not long enough for subsequent promotions. Not surprisingly, we find that female (male) visible minority immigrants who have been in Canada for less than six years have received an estimated $0.524(0.564)$ fewer promotions with their current employer when tenure is omitted, but only 0.325 (0.192) fewer promotions when tenure is included as a control. Omitting tenure accounts for $38 \%$ and $66 \%$ of the estimated promotion differentials in column 1 for female and male visible minority immigrants, respectively. We observe similarly large promotion differentials relative to white natives for newly arrived white immigrants as well when tenure is omitted. Clearly for newly arrived immigrants, omitting tenure leads to estimates that again significantly overstate the gaps in the number of promotions received between newly arrived immigrants and white natives.

By contrast, we find small differences between the estimates with and without tenure as a control for white and visible minority female immigrants and white male immigrants who have 
been in Canada for more than 20 years. Likewise, the estimates in columns 1 and 4 are almost identical for visible minority Canadian-born workers who have comparable tenure to their white native counterparts conditional on age and experience. Only among male visible minority immigrants who have been in Canada for more than 20 years do we observe a difference between the estimates with and without tenure as a control. These immigrants have received 0.2739 fewer promotions than observationally equivalent white natives when we omit tenure and 0.340 fewer promotions when tenure is included — though again we fail to reject equality of the estimates. On the whole, we infer again that the simultaneity bias in the estimates in column 4 is small and focus on the estimates with tenure as a control in columns 4 and 5 of tables 3a and 3b.

Controlling for tenure, we find no evidence that white immigrants fall behind their native peers by receiving fewer promotions with their current employers except among white male immigrants who have been in Canada for more than 20 years, who have received an estimated 0.128 fewer promotions than their native peers. Among visible minorities, the patterns are similar to those observed for the probability of promotion. Female visible minority immigrants who have been in Canada for less than six years have received an estimated 0.325 fewer promotions than an observationally equivalent white Canadian-born peer controlling for tenure with the employer. Using the within-firm estimator in column 5, these women have received an estimated 0.195 fewer promotions than their white Canadian-born peers, confirming that newly arrived female visible minority immigrants sort into firms offering fewer promotions than the firms in which their white Canadian-born peers are employed. We again find no evidence that this sorting persists. Female visible minority immigrants who have been in Canada for more than six years, between six and ten years, eleven to twenty years, and more than twenty years have received an estimated $0.099,0.166$, and 0.278 fewer promotions, respectively, than their white 
native peers, but these economy-wide differences are driven almost entirely by within-firm differences in promotion outcomes. The sorting of female visible minority immigrants into firms offering "dead-end" jobs is an issue among newly arrived immigrants, but within-firm differences in the number of promotions received exist for all female visible minority immigrants.

Newly arrived male visible minority immigrants were not less likely to have been promoted with their current employer according to the estimates in table $2 \mathrm{~b}$, but they received an estimated 0.192 fewer promotions with their current employers than have observationally equivalent white natives. Unlike newly arrived female visible minority immigrants, these men do not appear to sort into firms offering fewer promotion opportunities; firms simply promote them less often. Male visible minority and white immigrants who have been in Canada for more than 20 years have received an estimated 0.340 and 0.128 fewer promotions with their current employers, respectively, than have observationally equivalent white natives; among visible minority immigrants this is in part due to sorting into firms offering fewer promotion opportunities. As before, the re-emergence of a promotion outcome differential among immigrants who have been in Canada for more than 20 years may either reflect a failure to assimilate in the labor market or unobserved changes in immigrant cohort quality.

\section{IV.C Immigration, Promotion Outcomes, and Education}

Tables 4 ( $a$ and b) and 5 ( $a$ and b) report the estimates of the models of the probability of promotion and the number of times promoted interacting all of the regressors with an indicator for whether the worker has a bachelor's or higher degree. Tables 4a and 4b report the estimated promotion probability differentials for women and men, respectively, by education category with tenure included as a control; the estimates without tenure are provided in the appendix. Striking 
differences emerge among female visible minority immigrants. Female visible minority immigrants with less than a bachelor's degree are an estimated 17.4 percentage points less likely to have been promoted than observationally equivalent white Canadian-born women in their first five years in Canada — a gap which is driven almost entirely by the sorting of these women into firms offering fewer promotion opportunities. Further, while the sorting into firms offering fewer promotion opportunities abates among less educated female visible minority immigrants who have been in Canada for more than 5 years, these women continue to be more than 7 percentage points less likely to have been promoted than their white Canadian-born peers. Universityeducated female visible minority immigrants, on the other hand, are not statistically less likely at any point to have been promoted than comparable white Canadian-born women.

Using the number of times promoted as the dependent variable in tables $5 \mathrm{a}$ and $5 \mathrm{~b}$, female visible minority immigrants without a bachelor's degree who have been in Canada for less than 5 years have received an estimated 0.343 fewer promotions than their white native peers, and this is again almost entirely due to their being employed in firms that promote workers less often. This gap shrinks somewhat but remains statistically significant for less educated female visible minority immigrants who have been in Canada for more than 10 years, but among these immigrants intra-firm differences in promotion outcomes rather than systematic sorting into firms offering "dead-end" jobs account for the promotion outcome differential. Newly arrived university-educated female visible minority immigrants have received an estimated 0.213 fewer promotions than their white native peers-entirely the result of intra-firm differences in promotion outcomes—but other university-educated female visible minority immigrants have not been promoted fewer times than their white native peers. The p-values of the joint hypotheses that university-educated and less educated female visible minority immigrants 
experience the same promotion probabilities and numbers of promotions relative to their white native peers are 0.11 and 0.03 , respectively. Taken together, the estimates in tables $4 a$ and $5 a$ suggest that the promotion outcome differentials we observe in tables $2 \mathrm{a}$ and $3 \mathrm{a}$ largely reflect the advancement experiences of non-university educated female visible minority immigrants.

We do not observe comparable differences in promotion experiences for male visible minority immigrants with and without a university education. The only difference we observe is that newly arrived university-educated male visible minority immigrants have been promoted an estimated 0.274 fewer times than their white native peers while newly arrived non-university educated male visible minority immigrants have been promoted a similar number of times relative to their white native peers.

Among white immigrants, less educated immigrants are estimated to be between 16 and 18 percentage points more likely to have been promoted in their first 10 years in Canada, while all other white male immigrants of both education types are equally likely to have been promoted as their white native counterparts. Likewise, non-university educated white immigrants in their first ten years in Canada have been promoted more often than their white native peers while similar university-educated white immigrants have been promoted —if anything — fewer times than their white native peers. The p-values of the joint hypotheses that university-educated and less educated male white immigrants experience the same promotion probabilities and numbers of promotions relative to their white native peers are 0.01 and 0.14 , respectively.

\section{Discussion \& Conclusion}

We examine economy-wide differences between immigrants and natives in the probabilities of having been promoted and the number of times promoted for a linked sample of employers and employees in Canada between 1999 and 2005. We further investigate the heterogeneity in 
promotion experiences among immigrants based on how long they have been in Canada and their education levels. We find little evidence of significant differences in promotion outcomes for white immigrants relative to white natives. Male and female visible minority immigrants, on the other hand, are an estimated 4.7 and 7.6 percentage points less likely to have been promoted and have received 0.221 and 0.202 fewer promotions with their current employer, respectively, than observationally equivalent white Canadian-born workers. Immigrants' promotion experiences are very heterogeneous: primarily newly arrived immigrants and immigrants who have been in Canada for more than 20 years experience adverse promotion outcomes. Immigrants' education levels are also related to their promotion experiences. Female visible minority immigrants without a bachelor's degree are less likely to have been promoted and receive fewer promotions while university-educated female visible minority immigrants experience similar promotion outcomes relative to observationally equivalent white natives. By contrast, non-university educated white male immigrants in their first ten years in Canada are actually more likely to have been promoted and have been promoted more times than observationally equivalent white natives relative to university-educated white male immigrants. Similarly, newly arrived, nonuniversity-educated male visible minorities have been promoted more often than newly-arrived, university-educated male visible minorities.

Previous evidence suggesting that immigrants sort systematically into different firms in terms of wages than natives led us to investigate whether immigrants are disproportionately employed in firms offering "dead-end" jobs. We find only limited evidence of such sorting. Newly arrived female visible minority immigrants are indeed disproportionately employed in firms offering limited opportunities for advancement; this sorting is especially acute among newly arrived female visible minority immigrants without a bachelor's degree. Among other 
immigrants, we find that male visible minority immigrants who have been in Canada for more than 20 years are also employed in firms offering fewer opportunities for advancement.

Moving up on the job is an important contributor to wage growth over the life cycle. Aydemir and Skuterud (2008) and Pendakur and Woodcock (2010) provide evidence that the average economy-wide wage gaps experienced by male and female immigrants found in the previous literature result both from the disproportionate sorting of immigrants into lower-paying firms and from immigrants earning less than their peers within these firms. These findings provide support for employment equity policies that aim to help immigrants "get a foot in the door" at firms offering better wage prospects and pay equity policies that target wages within firms.

Our finding that immigrants—particularly newly arrived visible minority immigrants—are less likely to be promoted in the economy as a whole because they are less likely to be promoted within any given employer suggests that these policies may prove insufficient. Employment equity policies promoting equal employment opportunities at firms for all workers do not address a primary mechanism through which immigrants may fall behind in terms of wages: the failure to keep pace with their native peers in climbing the corporate ladder within firms once they have their "foot in the door." Similarly, pay equity policies do little to benefit immigrants if immigrants—even while earning equal pay for equal work—are less able to move up the ladder to more demanding — and higher paying—jobs. Existing antidiscrimination policies will be insufficient if these promotion outcome differentials are the result of discrimination. If discrimination is to blame for the adverse promotion experiences of immigrants and visible minorities more generally, then antidiscrimination policies must ensure that such workers face a level playing field within firms when competing for promotions. Our findings thus suggest that 
policy-makers seeking to assist immigrants should focus on within-firm processes that govern advancement on-the-job. 


\section{References}

Aydemir, Abdurrahman and Mikal Skuterud. 2008. "The Immigrant Wage Differential Within and Across Establishments.” Industrial and Labor Relations Review, 61(3), 334-352.

Aydemir, Abdurrahman. 2003. "Effects of business cycles on the labour market assimilation of immigrants.” in Canadian Immigration Policy for the 21st Century, Ed. Charles Beach and Alan Green (Kingston: Queen’s University Press)

Baker, Michael and Dwayne Benjamin. 1994. "The Performance of Immigrants in the Canadian Labor Market.” Journal of Labor Economics 12(3), 369-405.

Baker, G., M. Gibbs, and B. Holmstrom. 1994. “The Wage Policy of a Firm.' Quarterly Journal of Economics, 109(4), 921-955.

Borjas, George. 1985. "Assimilation, Changes in Cohort Quality, and the Earnings of Immigrants.” Journal of Labor Economics, 3, 463-89.

Borjas, George. 1994. “The Economics of Immigration.” Journal of Economic Literature, 32(4), 1667-1717.

Bloom, D., and M. Gunderson. 1991. “An Analysis of the Earnings of Canadian Immigrants.” In Immigration, Trade and the Labor Market, ed. J. Abowd and R. Freeman (Chicago: University of Chicago Press for the National Bureau of Economics Research).

Bloom, D., Gilles Grenier, and M. Gunderson . 1995. “The Changing Labour Market Position of Canadian Immigrants.” Canadian Journal of Economics, 28(4b): 987-1005.

Chiswick, Barry. 1978. “The Effect of Americanization on the Earnings of Foreign-Born Men.” Journal of Political Economy 86, 897-922.

Ferrer, Ana and W. Craig Riddell. 2008. "Education, credentials, and immigrant earnings." Canadian Journal of Economics, 41(1), 186-216.

Friedberg, Rachel M. 2000. "You Can’t Take It with You? Immigrant Assimilation and the Portability of Human Capital.” Journal of Labor Economics, 18, 221-252.

Green, David. 1999. "Immigrant Occupational Attainment: Assimilation and Mobility over Time.” Journal of Labor Economics, 17(1), 49-79.

Green, David A. \& Worswick, Christopher. 2012. "Immigrant earnings profiles in the presence of human capital investment: Measuring cohort and macro effects." Labour Economics, 19(2), 241-259. 
Greenhaus, J. H., Parasuraman, S., and Wormley W. M. 1990. "Effect of Race on Organizational Experience, Job Performance Evaluations, and Career Outcomes." Academy of Management Journal, 33, 64-86.

Hellerstein, Judith and David Neumark. 2008. "Workplace Segregation in the United States: Race, Ethnicity, and Skill.” Review of Economics and Statistics, 90(3), 459-477.

Hersch, Joni and W. Kip Viscusi. 1996. "Gender Differences in Promotions and Wages." Industrial Relations, 35(4), 461-72.

Javdani, Mohsen. 2012. "Glass Ceilings or Glass Doors? The Role of Firms in Male-Female Wage Disparities.” Working paper.

Lazear, Edward. 1992. "The Job as a Concept," in Performance Measurement, Evaluations, and Incentives, W. Bruns, ed. (Boston, MA: Harvard University Press, 1992), pp. 183-215.

MacDonald, James Ted and Christopher Worswick. 1998. "The Earnings of Immigrant Men in Canada: Job Tenure, Cohort, and Macroeconomic Conditions.” Industrial and Labor Relations Review, 51(3), 465-482.

McCue, Kristin. 1996. "Promotions and Wage Growth.” Journal of Labor Economics, 14(2), 175-209

Gerhart, B., and G. Milkovich. 1989. "Salaries, Salary Growth, and Promotions of Men and Women in a Large, Private Firm," in Pay Equity: Empirical Inquiries, R. Michael, H. Hartmann, and B. O’Farrell, eds. (Washington, DC: National Academy Press, 1989), pp. 23-43.

Nkomo, S. M. and Cox. T. Jr. 1990. "Factors Affecting the Upward Mobility of Black Managers in Private Sector Organizations.” Review of Black Political Economy, 19, 39-57.

Olson, Craig A. and Brian E. Becker. 1983. "Sex Discrimination in the Promotion Process." Industrial and Labor Relations Review, 36(4), 624-641.

Oreopoulos, Philip. 2011. "Why Do Skilled Immigrants Struggle in the Labor Market? A Field Experiment with Six Thousand Résumés” American Economic Journal: Economic Policy, 3(4), 148-171.

Pergamit, Michael R. and Jonathan R. Veum. 1999. “What is a Promotion?” Industrial and Labor Relations Review, 52(4), 581-601.

Pendakur, Krishna and Simon Woodcock. 2010. "Glass Ceilings or Glass Doors? Wage Disparity Within and Between Firms.” Journal of Business \& Economic Statistics, 28(1), 181-189. 
Sousa, Liliana D. 2011. "Human Capital Traps? Enclave Effects Using Linked EmployerHousehold Data.” Working paper.

Warman, Casey. 2007. "Ethnic Enclaves and Immigrant Earnings Growth.” Canadian Journal of Economics, 40(2), 401-422.

Waslander, Bert. 2003. “The Falling Earnings of New Immigrant Men in Canada's Large Cities.” In Canadian Immigration Policy for the 2lst Century, Ed. C. Beach, A. Green and J. Reitz. John Deutsch Institute for the Study of Economic Policy (Kingston: Queen's University Press)

Wilson, Kenneth L. and Alejandro Portes. 1980. "Immigrant Enclaves: An Analysis of the Labor Market Experience of Cubans in Miami.” The American Journal of Sociology, 86(2), 295-319 
Figure 1: Distributions of immigrants and natives by proportion of employer's sampled employees who are immigrants

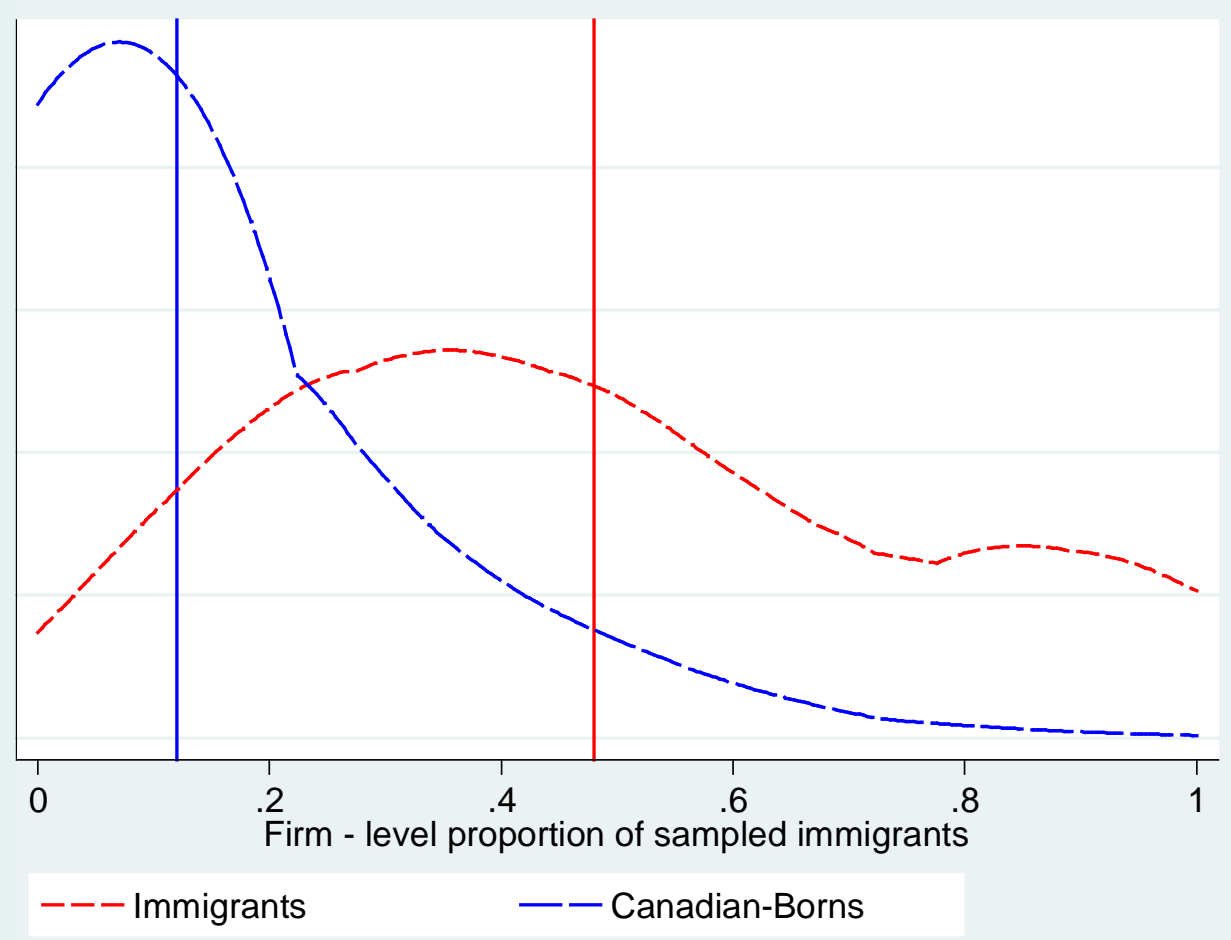


Figure 2: Promotion rate by proportion of firm's sampled employees who are immigrants

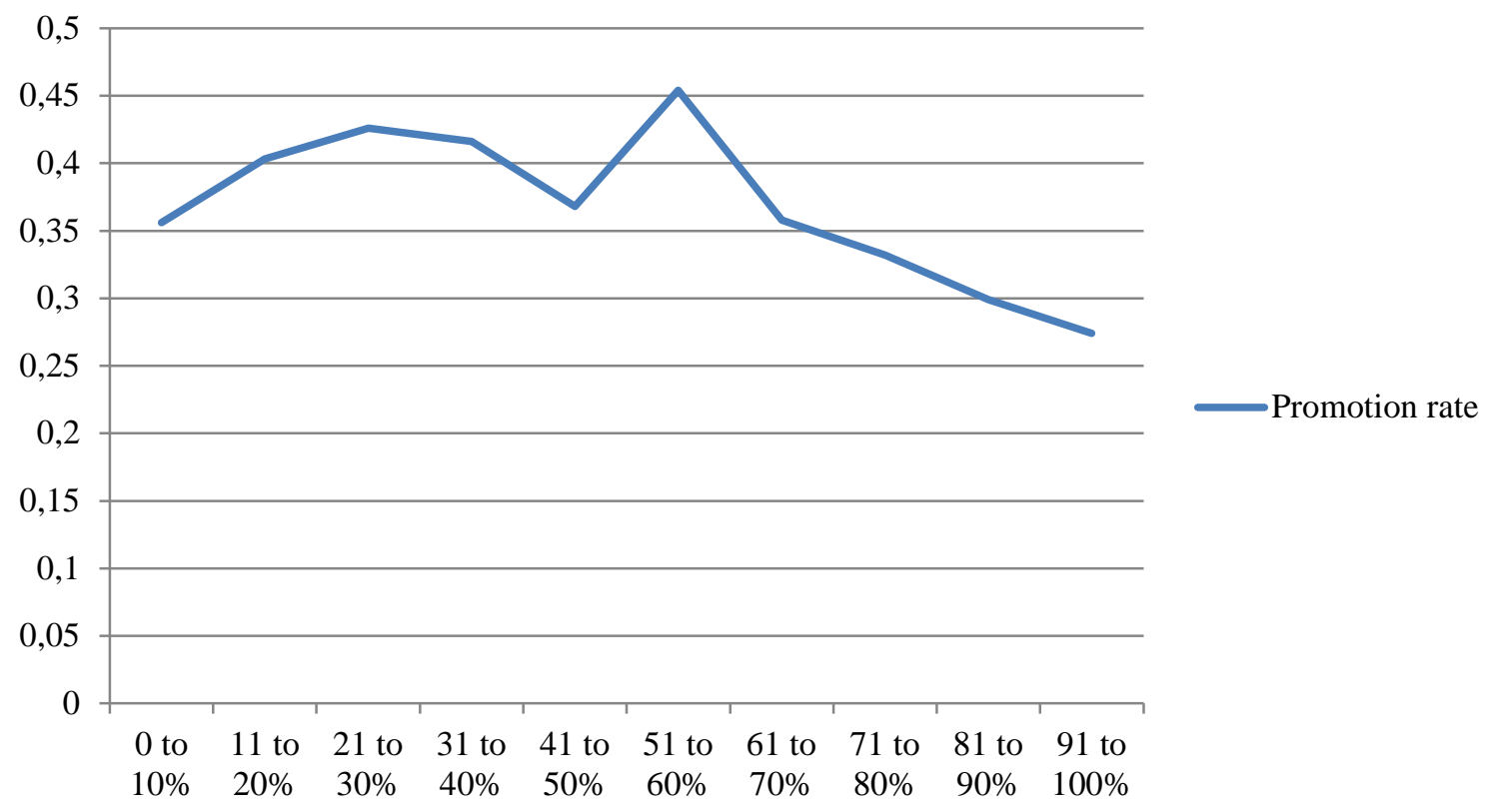

Figure 3: Number of promotions by proportion of firm's sampled employees who are immigrants

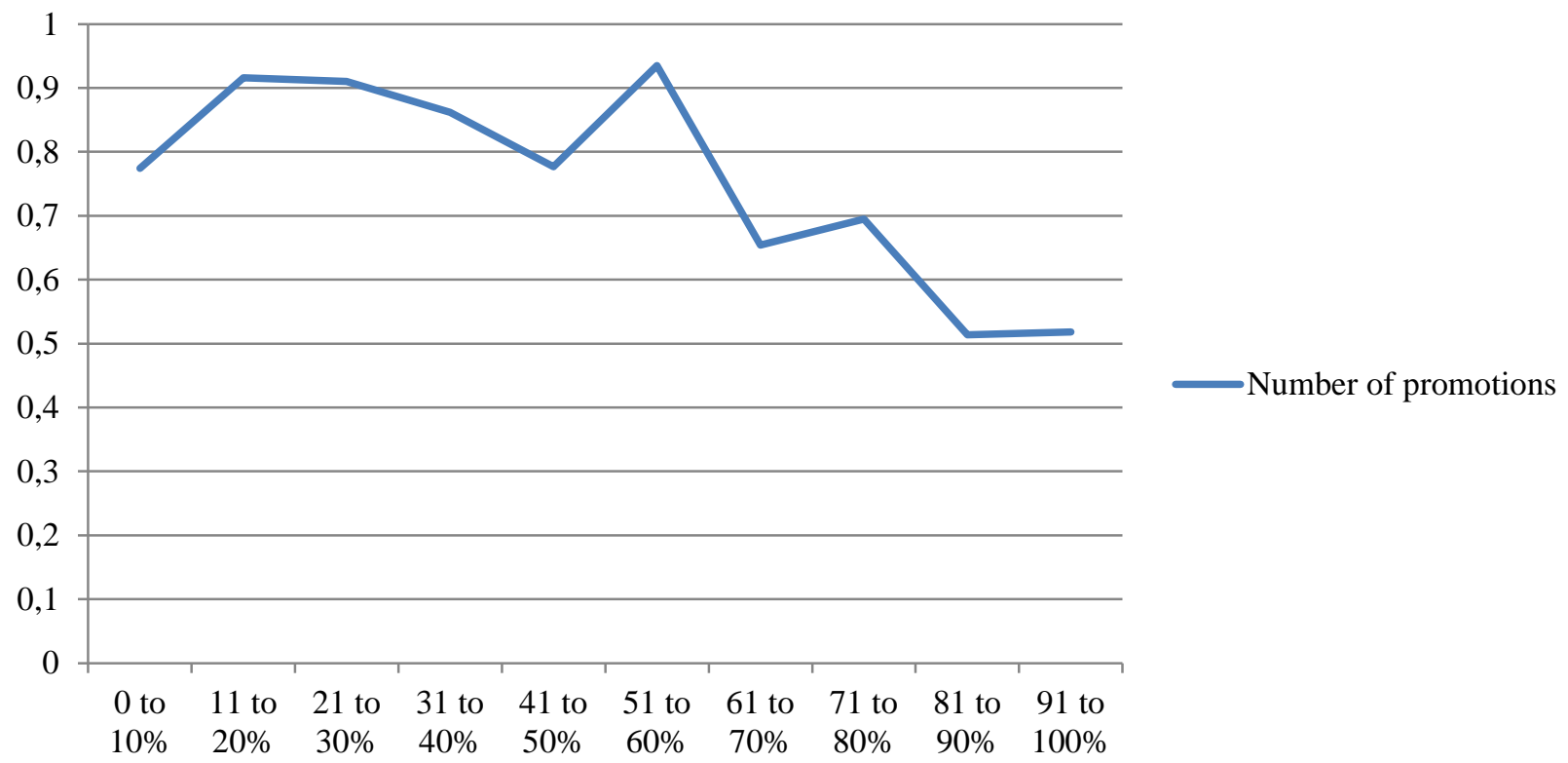


Table 1: Summary Statistics

\begin{tabular}{|c|c|c|c|c|c|c|c|c|}
\hline & \multicolumn{4}{|c|}{ Male } & \multicolumn{4}{|c|}{ Female } \\
\hline & \multicolumn{2}{|c|}{ Canadian-Born } & \multicolumn{2}{|c|}{ Immigrant } & \multicolumn{2}{|c|}{ Canadian-Born } & \multicolumn{2}{|c|}{ Immigrant } \\
\hline & White & $\begin{array}{c}\text { Visible } \\
\text { Minority }\end{array}$ & White & $\begin{array}{c}\text { Visible } \\
\text { Minority }\end{array}$ & White & $\begin{array}{c}\text { Visible } \\
\text { Minority }\end{array}$ & White & $\begin{array}{c}\text { Visible } \\
\text { Minority }\end{array}$ \\
\hline Number of observations & 34,797 & 625 & 4,265 & 2,780 & 26,276 & 516 & 3,147 & 2,464 \\
\hline Hourly wage & 24.082 & 22.998 & 25.727 & 20.216 & 18.827 & 17.793 & 19.275 & 17.451 \\
\hline Ever promoted & 0.420 & 0.373 & 0.409 & 0.339 & 0.353 & 0.314 & 0.342 & 0.288 \\
\hline $\begin{array}{l}\text { Number of times promoted } \\
\text { (including never promoted) }\end{array}$ & 0.996 & 0.743 & 0.879 & 0.637 & 0.705 & 0.700 & 0.702 & 0.471 \\
\hline \multicolumn{9}{|l|}{ Personal Characteristics: } \\
\hline Years of experience & 20.493 & 14.134 & 22.595 & 15.423 & 16.871 & 13.411 & 18.347 & 13.899 \\
\hline Years since Immigration & & & 26.269 & 16.103 & & & 27.580 & 17.063 \\
\hline 0 to 5 years (\% in category) & & & 6.93 & 17.20 & & & 6.89 & 15.66 \\
\hline 6 to 10 years (\% in category) & & & 8.85 & 18.30 & & & 7.37 & 18.59 \\
\hline 11 to 20 years (\% in category) & & & 19.36 & 30.71 & & & 18.17 & 27.15 \\
\hline 21 or more years (\% in category) & & & 64.87 & 33.79 & & & 67.57 & 38.60 \\
\hline 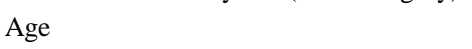 & 41.836 & 35.708 & 45.493 & 41.796 & 41.958 & 35.565 & 45.176 & 41.445 \\
\hline $25-29$ (\% in category) & 11.56 & 36.87 & 6.77 & 7.48 & 11.95 & 28.13 & 7.48 & 11.29 \\
\hline $30-34$ (\% in category) & 14.88 & 16.71 & 10.46 & 17.65 & 12.99 & 22.76 & 9.32 & 14.09 \\
\hline $35-39$ (\% in category) & 16.41 & 15.04 & 12.64 & 19.87 & 16.12 & 20.51 & 13.85 & 17.21 \\
\hline 40-44 (\% in category) & 17.46 & 14.33 & 15.67 & 18.56 & 18.64 & 13.75 & 13.84 & 19.18 \\
\hline 45-49 (\% in category) & 15.64 & 8.27 & 15.16 & 15.66 & 16.80 & 6.83 & 18.48 & 17.47 \\
\hline $50-54$ (\% in category) & 12.87 & 3.75 & 17.09 & 10.79 & 12.61 & 4.40 & 17.79 & 11.89 \\
\hline $55-59$ (\% in category) & 8.07 & 2.60 & 14.90 & 6.35 & 7.81 & 2.33 & 12.74 & 6.30 \\
\hline $60-65$ (\% in category) & 3.11 & 2.43 & 7.32 & 3.65 & 3.07 & 1.30 & 6.50 & 2.56 \\
\hline \multicolumn{9}{|l|}{ Highest educational attainment } \\
\hline Ph.D., Master's, or M.D & 0.040 & 0.037 & 0.093 & 0.083 & 0.036 & 0.040 & 0.068 & 0.073 \\
\hline Other graduate degree & 0.018 & 0.010 & 0.034 & 0.026 & 0.021 & 0.044 & 0.033 & 0.029 \\
\hline Bachelor's degree & 0.119 & 0.302 & 0.153 & 0.249 & 0.131 & 0.198 & 0.160 & 0.229 \\
\hline Some university & 0.082 & 0.105 & 0.076 & 0.076 & 0.086 & 0.122 & 0.079 & 0.063 \\
\hline Completed college & 0.164 & 0.158 & 0.171 & 0.196 & 0.255 & 0.221 & 0.246 & 0.253 \\
\hline Some college or trade certificate & 0.263 & 0.196 & 0.236 & 0.168 & 0.218 & 0.129 & 0.178 & 0.159 \\
\hline High school diploma & 0.175 & 0.116 & 0.135 & 0.118 & 0.176 & 0.233 & 0.143 & 0.132 \\
\hline Less than high school* & 0.135 & 0.072 & 0.098 & 0.079 & 0.074 & 0.008 & 0.090 & 0.057 \\
\hline \multicolumn{9}{|l|}{ Marital Status } \\
\hline Married & 0.595 & 0.484 & 0.717 & 0.796 & 0.570 & 0.439 & 0.661 & 0.676 \\
\hline Common law & 0.165 & 0.113 & 0.088 & 0.035 & 0.148 & 0.110 & 0.085 & 0.032 \\
\hline Separated & 0.024 & 0.022 & 0.030 & 0.017 & 0.036 & 0.028 & 0.031 & 0.030 \\
\hline Divorced & 0.038 & 0.023 & 0.027 & 0.019 & 0.079 & 0.033 & 0.076 & 0.060 \\
\hline Widowed & 0.005 & 0.001 & 0.003 & 0.002 & 0.014 & 0.001 & 0.021 & 0.017 \\
\hline Single* & 0.170 & 0.354 & 0.131 & 0.128 & 0.151 & 0.386 & 0.123 & 0.181 \\
\hline \multicolumn{9}{|l|}{ Number of Dependent Children } \\
\hline Zero* & 0.483 & 0.662 & 0.464 & 0.332 & 0.506 & 0.582 & 0.518 & 0.430 \\
\hline One & 0.173 & 0.131 & 0.189 & 0.223 & 0.177 & 0.167 & 0.170 & 0.231 \\
\hline Two & 0.245 & 0.128 & 0.247 & 0.313 & 0.233 & 0.162 & 0.211 & 0.260 \\
\hline Three & 0.076 & 0.065 & 0.073 & 0.102 & 0.067 & 0.076 & 0.080 & 0.060 \\
\hline Four or more & 0.020 & 0.012 & 0.025 & 0.027 & 0.014 & 0.010 & 0.019 & 0.017 \\
\hline \multicolumn{9}{|l|}{ Language most often spoken at home } \\
\hline French & 0.290 & 0.067 & 0.073 & 0.047 & 0.255 & 0.050 & 0.046 & 0.023 \\
\hline English & 0.698 & 0.835 & 0.669 & 0.364 & 0.731 & 0.777 & 0.692 & 0.414 \\
\hline Other & 0.010 & 0.096 & 0.257 & 0.587 & 0.012 & 0.171 & 0.260 & 0.561 \\
\hline
\end{tabular}

Notes: * indicates the reference category for regressions. All means are computed using sample weights provided in the data. Statistics Canada does not permit reporting these means without using the weights. 
Table 1 continued: Summary Statistics

\begin{tabular}{|c|c|c|c|c|c|c|c|c|}
\hline & \multicolumn{4}{|c|}{ Male } & \multicolumn{4}{|c|}{ Female } \\
\hline & \multicolumn{2}{|c|}{ Canadian-born } & \multicolumn{2}{|c|}{ Immigrant } & \multicolumn{2}{|c|}{ Canadian-born } & \multicolumn{2}{|c|}{ Immigrant } \\
\hline & White & $\begin{array}{c}\text { Visible } \\
\text { Minority }\end{array}$ & White & $\begin{array}{c}\text { Visible } \\
\text { Minority }\end{array}$ & White & $\begin{array}{c}\text { Visible } \\
\text { Minority }\end{array}$ & White & $\begin{array}{c}\text { Visible } \\
\text { Minority }\end{array}$ \\
\hline \multicolumn{9}{|l|}{ Geography } \\
\hline Atlantic & 0.076 & 0.034 & 0.017 & 0.002 & 0.087 & 0.022 & 0.019 & 0.005 \\
\hline Quebec & 0.296 & 0.157 & 0.157 & 0.129 & 0.258 & 0.111 & 0.108 & 0.081 \\
\hline Ontario* & 0.337 & 0.374 & 0.549 & 0.587 & 0.366 & 0.451 & 0.584 & 0.595 \\
\hline Manitoba & 0.036 & 0.036 & 0.033 & 0.035 & 0.040 & 0.022 & 0.032 & 0.023 \\
\hline Saskatchewan & 0.036 & 0.007 & 0.007 & 0.011 & 0.033 & 0.016 & 0.006 & 0.003 \\
\hline Alberta & 0.111 & 0.098 & 0.096 & 0.077 & 0.099 & 0.082 & 0.087 & 0.115 \\
\hline British Columbia & 0.105 & 0.291 & 0.137 & 0.157 & 0.113 & 0.291 & 0.161 & 0.175 \\
\hline Census Metropolitan Area (CMA) & 0.650 & 0.854 & 0.853 & 0.938 & 0.643 & 0.835 & 0.832 & 0.936 \\
\hline \multicolumn{9}{|l|}{ Job Characteristics: } \\
\hline Fulltime & 0.866 & 0.871 & 0.892 & 0.876 & 0.545 & 0.631 & 0.632 & 0.717 \\
\hline Member of Union or CBA & 0.289 & 0.222 & 0.256 & 0.194 & 0.303 & 0.199 & 0.237 & 0.191 \\
\hline Tenure with current employer & 10.111 & 6.279 & 10.111 & 6.987 & 8.976 & 6.691 & 8.722 & 6.673 \\
\hline 0 to 5 years since immigration & & & 2.721 & 1.931 & & & 2.092 & 2.244 \\
\hline 6 to 10 years since immigration & & & 4.658 & 4.872 & & & 3.865 & 4.847 \\
\hline 11 to 20 years since immigration & & & 6.946 & 6.776 & & & 5.764 & 6.314 \\
\hline 21 or more years since immigration & & & 12.589 & 10.900 & & & 10.724 & 9.603 \\
\hline \multicolumn{9}{|l|}{ Language most often spoken at work } \\
\hline French & 0.276 & 0.074 & 0.098 & 0.076 & 0.246 & 0.047 & 0.069 & 0.041 \\
\hline English & 0.716 & 0.913 & 0.875 & 0.832 & 0.747 & 0.942 & 0.906 & 0.864 \\
\hline Other & 0.006 & 0.011 & 0.025 & 0.091 & 0.006 & 0.009 & 0.023 & 0.094 \\
\hline Home and work language not the same & 0.031 & 0.015 & 0.026 & 0.018 & 0.027 & 0.011 & 0.021 & 0.009 \\
\hline \multicolumn{9}{|l|}{ Occupation } \\
\hline Manager & 0.183 & 0.180 & 0.217 & 0.162 & 0.094 & 0.122 & 0.085 & 0.090 \\
\hline Professional & 0.134 & 0.250 & 0.203 & 0.172 & 0.218 & 0.199 & 0.203 & 0.213 \\
\hline Technical/Trades & 0.535 & 0.366 & 0.438 & 0.459 & 0.321 & 0.336 & 0.354 & 0.351 \\
\hline Marketing/Sales & 0.026 & 0.063 & 0.030 & 0.040 & 0.093 & 0.087 & 0.073 & 0.073 \\
\hline Clerical/Administrative & 0.057 & 0.082 & 0.049 & 0.080 & 0.223 & 0.219 & 0.200 & 0.176 \\
\hline Production Worker* & 0.065 & 0.059 & 0.063 & 0.087 & 0.051 & 0.037 & 0.085 & 0.097 \\
\hline \multicolumn{9}{|l|}{ Industry } \\
\hline Resource & 0.031 & 0.011 & 0.010 & 0.006 & 0.005 & 0.002 & 0.005 & 0.018 \\
\hline Labor intensive tertiary manufacturing & 0.052 & 0.069 & 0.064 & 0.101 & 0.032 & 0.049 & 0.071 & 0.086 \\
\hline Secondary product manufacturing & 0.051 & 0.036 & 0.068 & 0.080 & 0.018 & 0.008 & 0.021 & 0.040 \\
\hline Capital intensive tertiary manufacturing & 0.068 & 0.076 & 0.115 & 0.128 & 0.028 & 0.008 & 0.032 & 0.031 \\
\hline Construction & 0.082 & 0.060 & 0.060 & 0.018 & 0.015 & 0.009 & 0.003 & 0.006 \\
\hline $\begin{array}{l}\text { Transportation, warehousing, } \\
\text { wholesale }\end{array}$ & 0.160 & 0.151 & 0.121 & 0.100 & 0.070 & 0.073 & 0.066 & 0.063 \\
\hline Communication and other utilities & 0.030 & 0.014 & 0.015 & 0.013 & 0.012 & 0.005 & 0.011 & 0.007 \\
\hline Retail trade and consumer services & 0.163 & 0.195 & 0.151 & 0.189 & 0.213 & 0.337 & 0.181 & 0.244 \\
\hline Finance and insurance & 0.027 & 0.051 & 0.022 & 0.051 & 0.071 & 0.089 & 0.047 & 0.072 \\
\hline Real estate, rental and leasing operations & 0.017 & 0.023 & 0.018 & 0.007 & 0.017 & 0.006 & 0.019 & 0.014 \\
\hline Business services & 0.095 & 0.101 & 0.140 & 0.159 & 0.097 & 0.119 & 0.141 & 0.150 \\
\hline Education and health services & 0.113 & 0.143 & 0.127 & 0.089 & 0.371 & 0.242 & 0.347 & 0.234 \\
\hline Information and cultural industries & 0.037 & 0.050 & 0.038 & 0.016 & 0.034 & 0.033 & 0.036 & 0.019 \\
\hline Primary product manufacturing* & 0.067 & 0.013 & 0.045 & 0.036 & 0.012 & 0.012 & 0.014 & 0.008 \\
\hline
\end{tabular}

Notes: * indicates the reference category for regressions. All means are computed using sample weights provided in the data. Statistics Canada does not permit reporting these means without using the weights. 


\begin{tabular}{|c|c|c|c|c|c|c|}
\hline & \multicolumn{3}{|c|}{ Without tenure } & \multicolumn{3}{|c|}{ With tenure } \\
\hline & $\begin{array}{l}\text { Economy-wide } \\
\text { (1) }\end{array}$ & $\begin{array}{l}\text { Within firms } \\
(2)\end{array}$ & $\begin{array}{l}\text { Sorting } \\
\text { (3) }\end{array}$ & $\begin{array}{l}\text { Economy-wide } \\
\text { (4) }\end{array}$ & $\begin{array}{l}\text { Within firms } \\
\text { (5) }\end{array}$ & $\begin{array}{l}\text { Sorting } \\
\text { (6) }\end{array}$ \\
\hline Visible Minority Canadian Born & $\begin{array}{l}-0.085 \\
(0.057)\end{array}$ & $\begin{array}{l}-0.066^{*} \\
(0.037)\end{array}$ & $\begin{array}{l}-0.019 \\
{[0.661]}\end{array}$ & $\begin{array}{l}-0.087^{*} \\
(0.050)\end{array}$ & $\begin{array}{l}-0.069 * * \\
(0.035)\end{array}$ & $\begin{array}{l}-0.018 \\
{[0.609]}\end{array}$ \\
\hline White Immigrant & $\begin{array}{l}-0.026 \\
(0.017)\end{array}$ & $\begin{array}{l}-0.021 \\
(0.018)\end{array}$ & $\begin{array}{l}-0.005 \\
{[0.398]}\end{array}$ & $\begin{array}{l}-0.016 \\
(0.017)\end{array}$ & $\begin{array}{l}-0.010 \\
(0.017)\end{array}$ & $\begin{array}{l}-0.006 \\
{[0.190]}\end{array}$ \\
\hline Visible Minority Immigrant & $\begin{array}{l}-0.095^{* * *} \\
(0.030)\end{array}$ & $\begin{array}{l}-0.065^{* *} \\
(0.026)\end{array}$ & $\begin{array}{c}-0.030 * * \\
{[0.045]}\end{array}$ & $\begin{array}{l}-0.076^{* *} \\
(0.031)\end{array}$ & $\begin{array}{l}-0.045 \\
(0.028)\end{array}$ & $\begin{array}{l}-0.031^{* *} \\
{[0.017]}\end{array}$ \\
\hline & \multicolumn{3}{|c|}{ Without tenure } & \multicolumn{3}{|c|}{ With tenure } \\
\hline & Economy-wide & Within firms & Sorting & Economy-wide & Within firms & Sorting \\
\hline Visible Minority Canadian Born & $\begin{array}{l}-0.087 \\
(0.057)\end{array}$ & $\begin{array}{l}-0.067 * \\
(0.037)\end{array}$ & $\begin{array}{l}-0.02 \\
{[0.644]}\end{array}$ & $\begin{array}{l}-0.087 * \\
(0.050)\end{array}$ & $\begin{array}{l}-0.069 * * \\
(0.035)\end{array}$ & $\begin{array}{l}-0.018 \\
{[0.614]}\end{array}$ \\
\hline White Immigrant after 0 to 5 years & $\begin{array}{l}-0.086 \\
(0.056)\end{array}$ & $\begin{array}{l}-0.074 \\
(0.054)\end{array}$ & $\begin{array}{l}-0.012 \\
{[0.418]}\end{array}$ & $\begin{array}{l}-0.004 \\
(0.058)\end{array}$ & $\begin{array}{l}-0.011 \\
(0.056)\end{array}$ & $\begin{array}{l}0.006 \\
{[0.659]}\end{array}$ \\
\hline White Immigrant after 6 to 10 years & $\begin{array}{l}-0.047 \\
(0.064)\end{array}$ & $\begin{array}{l}-0.060 \\
(0.053)\end{array}$ & $\begin{array}{l}0.013 \\
{[0.726]}\end{array}$ & $\begin{array}{l}0.007 \\
(0.060)\end{array}$ & $\begin{array}{l}-0.004 \\
(0.052)\end{array}$ & $\begin{array}{l}0.011 \\
{[0.720]}\end{array}$ \\
\hline $\begin{array}{l}\text { White Immigrant after } 11 \text { to } 20 \\
\quad \text { years }\end{array}$ & $\begin{array}{l}-0.030 \\
(0.042)\end{array}$ & $\begin{array}{l}-0.024 \\
(0.042)\end{array}$ & $\begin{array}{l}0.006^{*} \\
{[0.053]}\end{array}$ & $\begin{array}{l}0.002 \\
(0.043)\end{array}$ & $\begin{array}{l}0.007 \\
(0.042)\end{array}$ & $\begin{array}{l}-0.005 \\
{[0.619]}\end{array}$ \\
\hline White Immigrant after 21 years & $\begin{array}{l}-0.019 \\
(0.021)\end{array}$ & $\begin{array}{l}-0.012 \\
(0.022)\end{array}$ & $\begin{array}{l}-0.007 \\
{[0.297]}\end{array}$ & $\begin{array}{l}-0.023 \\
(0.020)\end{array}$ & $\begin{array}{l}-0.014 \\
(0.020)\end{array}$ & $\begin{array}{l}-0.009 * * \\
{[0.038]}\end{array}$ \\
\hline $\begin{array}{l}\text { Visible Minority Immigrant after } \\
0 \text { to } 5 \text { years }\end{array}$ & $\begin{array}{l}-0.214^{* * *} \\
(0.043)\end{array}$ & $\begin{array}{l}-0.146^{* * *} \\
(0.038)\end{array}$ & $\begin{array}{l}-0.068 * * * \\
{[0.000]}\end{array}$ & $\begin{array}{l}-0.146^{* * *} \\
(0.043)\end{array}$ & $\begin{array}{l}-0.071^{*} \\
(0.037)\end{array}$ & $\begin{array}{l}-0.075^{* * *} \\
{[0.000]}\end{array}$ \\
\hline $\begin{array}{l}\text { Visible Minority Immigrant after } \\
6 \text { to } 10 \text { years }\end{array}$ & $\begin{array}{l}-0.092 * \\
(0.053)\end{array}$ & $\begin{array}{l}-0.073 \\
(0.054)\end{array}$ & $\begin{array}{l}-0.018^{*} \\
{[0.071]}\end{array}$ & $\begin{array}{l}-0.055 \\
(0.053)\end{array}$ & $\begin{array}{l}-0.037 \\
(0.054)\end{array}$ & $\begin{array}{l}-0.018 \\
{[0.131}\end{array}$ \\
\hline $\begin{array}{l}\text { Visible Minority Immigrant after } \\
11 \text { to } 20 \text { years }\end{array}$ & $\begin{array}{l}-0.065^{*} \\
(0.038)\end{array}$ & $\begin{array}{l}-0.033 \\
(0.045)\end{array}$ & $\begin{array}{l}-0.031 \\
{[0.181]}\end{array}$ & $\begin{array}{l}-0.048 \\
(0.037)\end{array}$ & $\begin{array}{l}-0.019 \\
(0.046)\end{array}$ & $\begin{array}{l}-0.029 \\
{[0.286]}\end{array}$ \\
\hline $\begin{array}{l}\text { Visible Minority Immigrant after } \\
21 \text { years }\end{array}$ & $\begin{array}{l}-0.079 * * \\
(0.034)\end{array}$ & $\begin{array}{l}-0.060 * \\
(0.031)\end{array}$ & $\begin{array}{l}-0.019 \\
{[0.163]}\end{array}$ & $\begin{array}{l}-0.072^{* *} \\
(0.035)\end{array}$ & $\begin{array}{l}-0.051 \\
(0.031)\end{array}$ & $\begin{array}{l}-0.022 \\
{[0.160]}\end{array}$ \\
\hline
\end{tabular}

Notes: Standard errors are in parentheses; p-values for the Hausman test of the equality of the economy-wide and within-firm estimates are in brackets. The reference group for all regressions is white Canadian-born. *** indicates statistically significant at $1 \%$, ** indicates statistically significant at $5 \%$, and * indicates statistically significant at $10 \%$. All coefficients are estimated using sampling weights provided by Statistics Canada, and the standard errors are computed using 100 sets of bootstrap weights provided by Statistics Canada. Controls include the personal characteristics, job characteristics, and geography controls detailed in Table 1 (excluding industry and occupation). 


\begin{tabular}{|c|c|c|c|c|c|c|}
\hline & \multicolumn{3}{|c|}{ Without tenure } & \multicolumn{3}{|c|}{ With tenure } \\
\hline & $\begin{array}{l}\text { Economy-wide } \\
\text { (1) }\end{array}$ & $\begin{array}{l}\text { Within firms } \\
(2)\end{array}$ & $\begin{array}{l}\text { Sorting } \\
\text { (3) }\end{array}$ & $\begin{array}{l}\text { Economy-wide } \\
(4)\end{array}$ & $\begin{array}{l}\text { Within firms } \\
\text { (5) }\end{array}$ & $\begin{array}{l}\text { Sorting } \\
(6)\end{array}$ \\
\hline Visible Minority Canadian Born & $\begin{array}{l}-0.084^{* *} \\
(0.040)\end{array}$ & $\begin{array}{l}-0.098^{* *} \\
(0.046)\end{array}$ & $\begin{array}{l}0.014 \\
{[0.537]}\end{array}$ & $\begin{array}{l}-0.080^{*} \\
(0.045)\end{array}$ & $\begin{array}{l}-0.098^{*} \\
(0.052)\end{array}$ & $\begin{array}{l}0.018 \\
{[0.468]}\end{array}$ \\
\hline White Immigrant & $\begin{array}{l}-0.007 \\
(0.019)\end{array}$ & $\begin{array}{l}-0.019 \\
(0.016)\end{array}$ & $\begin{array}{l}0.012 \\
{[0.241]}\end{array}$ & $\begin{array}{l}-0.004 \\
(0.018)\end{array}$ & $\begin{array}{l}-0.016 \\
(0.016)\end{array}$ & $\begin{array}{l}0.012 \\
{[0.180]}\end{array}$ \\
\hline Visible Minority Immigrant & $\begin{array}{l}-0.060 * * * \\
(0.020)\end{array}$ & $\begin{array}{l}-0.051^{* * *} \\
(0.019)\end{array}$ & $\begin{array}{l}-0.009 \\
{[0.149]}\end{array}$ & $\begin{array}{l}-0.047 * * \\
(0.019)\end{array}$ & $\begin{array}{l}-0.049 * * \\
(0.020)\end{array}$ & $\begin{array}{l}0.001 \\
{[0.772]}\end{array}$ \\
\hline & \multicolumn{3}{|c|}{ Without tenure } & \multicolumn{3}{|c|}{ With tenure } \\
\hline & Economy-wide & Within firms & Sorting & Economy-wide & Within firms & Sorting \\
\hline Visible Minority Canadian Born & $\begin{array}{l}-0.083^{* *} \\
(0.040)\end{array}$ & $\begin{array}{l}-0.098 * * \\
(0.047)\end{array}$ & $\begin{array}{l}0.015 \\
{[0.543]}\end{array}$ & $\begin{array}{l}-0.076^{*} \\
(0.045)\end{array}$ & $\begin{array}{l}-0.095^{*} \\
(0.052)\end{array}$ & $\begin{array}{l}0.019 \\
{[0.445]}\end{array}$ \\
\hline White Immigrant after 0 to 5 years & $\begin{array}{l}-0.019 \\
(0.053)\end{array}$ & $\begin{array}{l}0.038 \\
(0.055)\end{array}$ & $\begin{array}{l}-0.057 * * * \\
{[0.000}\end{array}$ & $\begin{array}{l}0.079 \\
(0.054)\end{array}$ & $\begin{array}{l}0.117^{* *} \\
(0.052)\end{array}$ & $\begin{array}{l}-0.038 * * * \\
{[0.001]}\end{array}$ \\
\hline White Immigrant after 6 to 10 years & $\begin{array}{l}0.029 \\
(0.043)\end{array}$ & $\begin{array}{l}0.025 \\
(0.050)\end{array}$ & $\begin{array}{l}0.004 \\
{[0.875]}\end{array}$ & $\begin{array}{l}0.084 * * \\
(0.038)\end{array}$ & $\begin{array}{l}0.065 \\
(0.041)\end{array}$ & $\begin{array}{l}0.019 \\
{[0.260]}\end{array}$ \\
\hline $\begin{array}{l}\text { White Immigrant after } 11 \text { to } 20 \\
\text { years }\end{array}$ & $\begin{array}{l}0.031 \\
(0.045)\end{array}$ & $\begin{array}{l}-0.006 \\
(0.039)\end{array}$ & $\begin{array}{l}0.037^{*} \\
{[0.099]}\end{array}$ & $\begin{array}{l}0.043 \\
(0.045)\end{array}$ & $\begin{array}{l}0.014 \\
(0.037)\end{array}$ & $\begin{array}{l}0.029 \\
{[0.251]}\end{array}$ \\
\hline White Immigrant after 21 years & $\begin{array}{l}-0.021 \\
(0.021)\end{array}$ & $\begin{array}{l}-.032 * \\
(0.018)\end{array}$ & $\begin{array}{l}0.011 \\
{[0.309]}\end{array}$ & $\begin{array}{l}-0.029 \\
(0.020)\end{array}$ & $\begin{array}{l}-0.039 * * \\
(0.018)\end{array}$ & $\begin{array}{l}0.010 \\
{[0.276]}\end{array}$ \\
\hline $\begin{array}{l}\text { Visible Minority Immigrant after } \\
0 \text { to } 5 \text { years }\end{array}$ & $\begin{array}{l}-0.144^{* * *} \\
(0.055)\end{array}$ & $\begin{array}{l}-0.118^{*} \\
(0.061)\end{array}$ & $\begin{array}{l}-0.026 \\
{[0.324]}\end{array}$ & $\begin{array}{l}-0.034 \\
(0.051)\end{array}$ & $\begin{array}{l}-0.038 \\
(0.061)\end{array}$ & $\begin{array}{l}0.005 \\
{[0.888}\end{array}$ \\
\hline $\begin{array}{l}\text { Visible Minority Immigrant after } \\
6 \text { to } 10 \text { years }\end{array}$ & $\begin{array}{l}0.000 \\
(0.053)\end{array}$ & $\begin{array}{l}-0.020 \\
(0.049)\end{array}$ & $\begin{array}{l}0.020 \\
{[0.319]}\end{array}$ & $\begin{array}{l}0.060 \\
(0.052)\end{array}$ & $\begin{array}{l}0.030 \\
(0.047)\end{array}$ & $\begin{array}{l}0.030 \\
{[0.171]}\end{array}$ \\
\hline $\begin{array}{l}\text { Visible Minority Immigrant after } \\
11 \text { to } 20 \text { years }\end{array}$ & $\begin{array}{l}-0.009 \\
(0.034)\end{array}$ & $\begin{array}{l}0.008 \\
(0.036)\end{array}$ & $\begin{array}{l}-0.017 \\
{[0.150]}\end{array}$ & $\begin{array}{l}0.000 \\
(0.031)\end{array}$ & $\begin{array}{l}0.002 \\
(0.033)\end{array}$ & $\begin{array}{l}-0.001 \\
{[0.908]}\end{array}$ \\
\hline $\begin{array}{l}\text { Visible Minority Immigrant after } \\
21 \text { years }\end{array}$ & $\begin{array}{l}-0.082^{* * * *} \\
(0.025)\end{array}$ & $\begin{array}{l}-.068 * * * \\
(0.025)\end{array}$ & $\begin{array}{l}-0.014 * * * \\
{[0.000]}\end{array}$ & $\begin{array}{l}-0.101^{* * *} \\
(0.024)\end{array}$ & $\begin{array}{l}-0.086 * * * \\
(0.026)\end{array}$ & $\begin{array}{l}-0.014^{*} \\
{[0.085]}\end{array}$ \\
\hline
\end{tabular}

Notes: Standard errors are in parentheses; p-values for the Hausman test of the equality of the economy-wide and within-firm estimates are in brackets. The reference group for all regressions is white Canadian-born. *** indicates statistically significant at $1 \%$, ** indicates statistically significant at $5 \%$, and * indicates statistically significant at $10 \%$. All coefficients are estimated using sampling weights provided by Statistics Canada, and the standard errors are computed using 100 sets of bootstrap weights provided by Statistics Canada. Controls include the personal characteristics, job characteristics, and geography controls detailed in Table 1 (excluding industry and occupation). 
Table 3a: Estimated Relationships between Minority Status and Number of Times Promoted for Women

\begin{tabular}{|c|c|c|c|c|c|c|}
\hline & \multicolumn{3}{|c|}{ Without tenure } & \multicolumn{3}{|c|}{ With tenure } \\
\hline & $\begin{array}{l}\text { Economy-wide } \\
\text { (1) }\end{array}$ & $\begin{array}{l}\text { Within firms } \\
\text { (2) }\end{array}$ & $\begin{array}{l}\text { Sorting } \\
\text { (3) }\end{array}$ & $\begin{array}{l}\text { Economy-wide } \\
(4)\end{array}$ & $\begin{array}{l}\text { Within firms } \\
\text { (5) }\end{array}$ & $\begin{array}{l}\text { Sorting } \\
(6)\end{array}$ \\
\hline \multirow[t]{2}{*}{ Visible Minority Canadian Born } & -0.076 & -0.030 & -0.046 & -0.079 & -0.039 & -0.040 \\
\hline & $(0.122)$ & $(0.092)$ & {$[0.565$} & $(0.100)$ & $(0.080)$ & [0.499] \\
\hline \multirow[t]{2}{*}{ White Immigrant } & -0.048 & -0.065 & 0.017 & -0.009 & -0.029 & 0.020 \\
\hline & $(0.052)$ & $(0.044)$ & [0.539] & $(0.051)$ & $(0.042)$ & {$[0.482]$} \\
\hline \multirow[t]{4}{*}{ Visible Minority Immigrant } & $-0.265^{* * *}$ & $-0.233 * * *$ & -0.032 & $-0.202 * * *$ & $-0.172 * * *$ & -0.030 \\
\hline & $(0.057)$ & $(0.044)$ & [0.377] & $(0.056)$ & $(0.044)$ & {$[0.371]$} \\
\hline & \multicolumn{3}{|c|}{ Without tenure } & \multicolumn{3}{|c|}{ With tenure } \\
\hline & Economy-wide & Within firms & Sorting & Economy-wide & Within firms & Sorting \\
\hline \multirow{2}{*}{ Visible Minority Canadian Born } & -0.083 & -0.035 & -0.048 & -0.079 & -0.040 & -0.039 \\
\hline & $(0.121)$ & $(0.092)$ & [0.541] & $(0.101)$ & $(0.080)$ & {$[0.521]$} \\
\hline \multirow[t]{2}{*}{ White Immigrant after 0 to 5 years } & -0.196 & -0.066 & $-0.13^{* *}$ & 0.047 & 0.106 & -0.059 \\
\hline & $(0.120)$ & $(0.105)$ & {$[0.025]$} & $(0.128)$ & $(0.113)$ & {$[0.326]$} \\
\hline \multirow[t]{2}{*}{ White Immigrant after 6 to 10 years } & -0.179 & $-0.193 *$ & 0.013 & -0.000 & -0.023 & 0.023 \\
\hline & $(0.135)$ & $(0.101)$ & [0.881] & $(0.121)$ & $(0.099)$ & {$[0.745]$} \\
\hline \multirow{2}{*}{$\begin{array}{l}\text { White Immigrant after } 11 \text { to } 20 \\
\quad \text { years }\end{array}$} & $-0.158 * *$ & $-0.192 * *$ & 0.033 & -0.042 & -0.090 & 0.047 \\
\hline & $(0.072)$ & $(0.083)$ & {$[0.430]$} & $(0.073)$ & $(0.082)$ & {$[0.207]$} \\
\hline \multirow[t]{2}{*}{ White Immigrant after 21 years } & 0.004 & -0.022 & 0.026 & -0.005 & -0.026 & 0.021 \\
\hline & $(0.074)$ & $(.059)$ & {$[0.556]$} & $(0.071)$ & $(0.056)$ & {$[0.625]$} \\
\hline Visible Minority Immigrant after & $-0.524 * * *$ & $-0.398 * * *$ & $-0.126^{* * *}$ & $-0.325 * * *$ & $-0.195 * *$ & $-0.130^{* * *}$ \\
\hline 0 to 5 years & $(0.071)$ & $(0.078)$ & {$[0.000]$} & $(0.067)$ & $(0.077)$ & {$[0.000]$} \\
\hline Visible Minority Immigrant after & $-0.217^{*}$ & $-0.189 * *$ & -0.028 & -0.099 & -0.086 & -0.013 \\
\hline 6 to 10 years & $(0.115)$ & $(0.087)$ & {$[0.716]$} & $(0.108)$ & $(0.081)$ & {$[0.860]$} \\
\hline Visible Minority Immigrant after & $-0.234 * * *$ & $-0.192 * * *$ & $-0.042 *$ & $-0.166^{* *}$ & $-0.141^{* *}$ & -0.025 \\
\hline 11 to 20 years & $(0.074)$ & $(0.070)$ & {$[0.052]$} & $(0.065)$ & $(0.069)$ & {$[0.313]$} \\
\hline Visible Minority Immigrant after & $-0.240^{* * *}$ & $-0.240 * * *$ & 0.000 & $-0.218^{* * *}$ & $-0.211^{* * *}$ & -0.007 \\
\hline 21 years & $(0.066)$ & $(0.066)$ & [0.999] & $(0.066)$ & $(0.063)$ & {$[0.702]$} \\
\hline
\end{tabular}

Notes: Standard errors are in parentheses; p-values for the Hausman test of the equality of the economy-wide and within-firm estimates are in brackets. The reference group for all regressions is white Canadian-born. *** indicates statistically significant at $1 \%$, ** indicates statistically significant at $5 \%$, and * indicates statistically significant at $10 \%$. All coefficients are estimated using sampling weights provided by Statistics Canada, and the standard errors are computed using 100 sets of bootstrap weights provided by Statistics Canada. Controls include the personal characteristics, job characteristics, and geography controls detailed in Table 1 (excluding industry and occupation). 


\section{Table 3b: Estimated Relationships between Minority Status and Number of Times}

\section{Promoted for Men}

\begin{tabular}{|c|c|c|c|c|c|c|}
\hline & \multicolumn{3}{|c|}{ Without tenure } & \multicolumn{3}{|c|}{ With tenure } \\
\hline & $\begin{array}{l}\text { Economy-wide } \\
\text { (1) }\end{array}$ & $\begin{array}{l}\text { Within firms } \\
\text { (2) }\end{array}$ & $\begin{array}{l}\text { Sorting } \\
\text { (3) }\end{array}$ & $\begin{array}{l}\text { Economy-wide } \\
\text { (4) }\end{array}$ & $\begin{array}{l}\text { Within firms } \\
\text { (5) }\end{array}$ & $\begin{array}{l}\text { Sorting } \\
\text { (6) }\end{array}$ \\
\hline \multirow{2}{*}{ Visible Minority Canadian Born } & $-0.280 * *$ & $-0.330 * *$ & 0.05 & $-0.262 *$ & $-0.322 * *$ & $0.06^{* * *}$ \\
\hline & $(0.123)$ & $(0.130)$ & [0.234] & $(0.140)$ & $(0.141)$ & {$[0.000]$} \\
\hline \multirow{2}{*}{ White Immigrant } & $-0.122 * *$ & $-0.116^{* *}$ & -0.006 & $-0.094 *$ & $-0.091 *$ & -0.003 \\
\hline & $(0.059)$ & $(0.046)$ & {$[0.870]$} & $(0.056)$ & $(0.047)$ & {$[0.924]$} \\
\hline \multirow[t]{4}{*}{ Visible Minority Immigrant } & $-0.274 * * *$ & $-0.171^{* * *}$ & $-0.103^{* * *}$ & $-0.221^{* * *}$ & $-0.170 * * *$ & $-0.051^{* * *}$ \\
\hline & $(0.063)$ & $(0.062)$ & {$[0.000]$} & $(0.058)$ & $(0.061)$ & {$[0.008]$} \\
\hline & \multicolumn{3}{|c|}{ Without tenure } & \multicolumn{3}{|c|}{ With tenure } \\
\hline & Economy-wide & Within firms & Sorting & Economy-wide & Within firms & Sorting \\
\hline \multirow{2}{*}{ Visible Minority Canadian Born } & $-0.285^{* *}$ & $-0.334 * *$ & 0.049 & $-0.255^{*}$ & $-0.318^{* *}$ & $0.063^{* * *}$ \\
\hline & $(0.123)$ & $(0.132)$ & {$[0.306]$} & $(0.141)$ & $(0.142)$ & {$[0.000]$} \\
\hline \multirow[t]{2}{*}{ White Immigrant after 0 to 5 years } & $-0.354 * * *$ & $-0.343^{* * *}$ & -0.011 & -0.013 & -0.075 & 0.062 \\
\hline & $(0.106)$ & $(0.130)$ & [0.883] & $(0.087)$ & $(0.112)$ & {$[0.379]$} \\
\hline \multirow[t]{2}{*}{ White Immigrant after 6 to 10 years } & -.1677 & -.1246 & -0.043 & 0.051 & 0.030 & 0.020 \\
\hline & $(.1188)$ & $(.1108)$ & [0.314] & $(0.100)$ & $(0.102)$ & {$[0.314]$} \\
\hline \multirow{2}{*}{$\begin{array}{l}\text { White Immigrant after } 11 \text { to } 20 \\
\text { years }\end{array}$} & -.0930 & -.1552 & 0.062 & -0.019 & -0.063 & 0.044 \\
\hline & $(.1327)$ & $(.1246)$ & {$[0.173]$} & $(0.122)$ & $(0.112)$ & {$[0.367]$} \\
\hline \multirow[t]{2}{*}{ White Immigrant after 21 years } & $-.1075 *$ & $-.0883^{*}$ & -0.019 & $-0.128 * *$ & $-0.106 *$ & -0.022 \\
\hline & $(.0657)$ & $(.0542)$ & {$[0.605]$} & $(0.062)$ & $(0.056)$ & {$[0.422]$} \\
\hline \multirow{2}{*}{$\begin{array}{l}\text { Visible Minority Immigrant after } \\
0 \text { to } 5 \text { years }\end{array}$} & $-0.564^{* * *}$ & $-0.459^{* * *}$ & -0.105 & $-0.192 * *$ & $-0.219 *$ & 0.027 \\
\hline & $(0.102)$ & $(0.138)$ & {$[0.258]$} & $(0.084)$ & $(0.130)$ & {$[0.786]$} \\
\hline \multirow{2}{*}{$\begin{array}{l}\text { Visible Minority Immigrant after } \\
6 \text { to } 10 \text { years }\end{array}$} & $-.2652 * *$ & $-.2071^{* *}$ & -0.058 & -0.039 & -0.034 & -0.005 \\
\hline & (.1086) & $(.0932)$ & [0.297] & $(0.106)$ & $(0.088)$ & {$[0.936]$} \\
\hline \multirow{2}{*}{$\begin{array}{l}\text { Visible Minority Immigrant after } \\
11 \text { to } 20 \text { years }\end{array}$} & $-.1677 *$ & -.0422 & $-0.125^{* * *}$ & -0.112 & -0.054 & -0.058 \\
\hline & (.0949) & $(.0998)$ & {$[0.000]$} & $(0.085)$ & $(0.096)$ & {$[0.208]$} \\
\hline \multirow{2}{*}{$\begin{array}{l}\text { Visible Minority Immigrant after } \\
21 \text { years }\end{array}$} & $-.2739 * * *$ & $-.1809 * *$ & $-0.093^{* * *}$ & $-0.340 * * *$ & $-0.255^{* * *}$ & $-0.085^{* * *}$ \\
\hline & (.0799) & $(.0737)$ & [0.002] & $(0.073)$ & $(0.072)$ & {$[0.000]$} \\
\hline
\end{tabular}

Notes: Standard errors are in parentheses; p-values for the Hausman test of the equality of the economy-wide and within-firm estimates are in brackets. The reference group for all regressions is white Canadian-born. *** indicates statistically significant at $1 \%$, ** indicates statistically significant at $5 \%$, and * indicates statistically significant at $10 \%$. All coefficients are estimated using sampling weights provided by Statistics Canada, and the standard errors are computed using 100 sets of bootstrap weights provided by Statistics Canada. Controls include the personal characteristics, job characteristics, and geography controls detailed in Table 1 (excluding industry and occupation). 


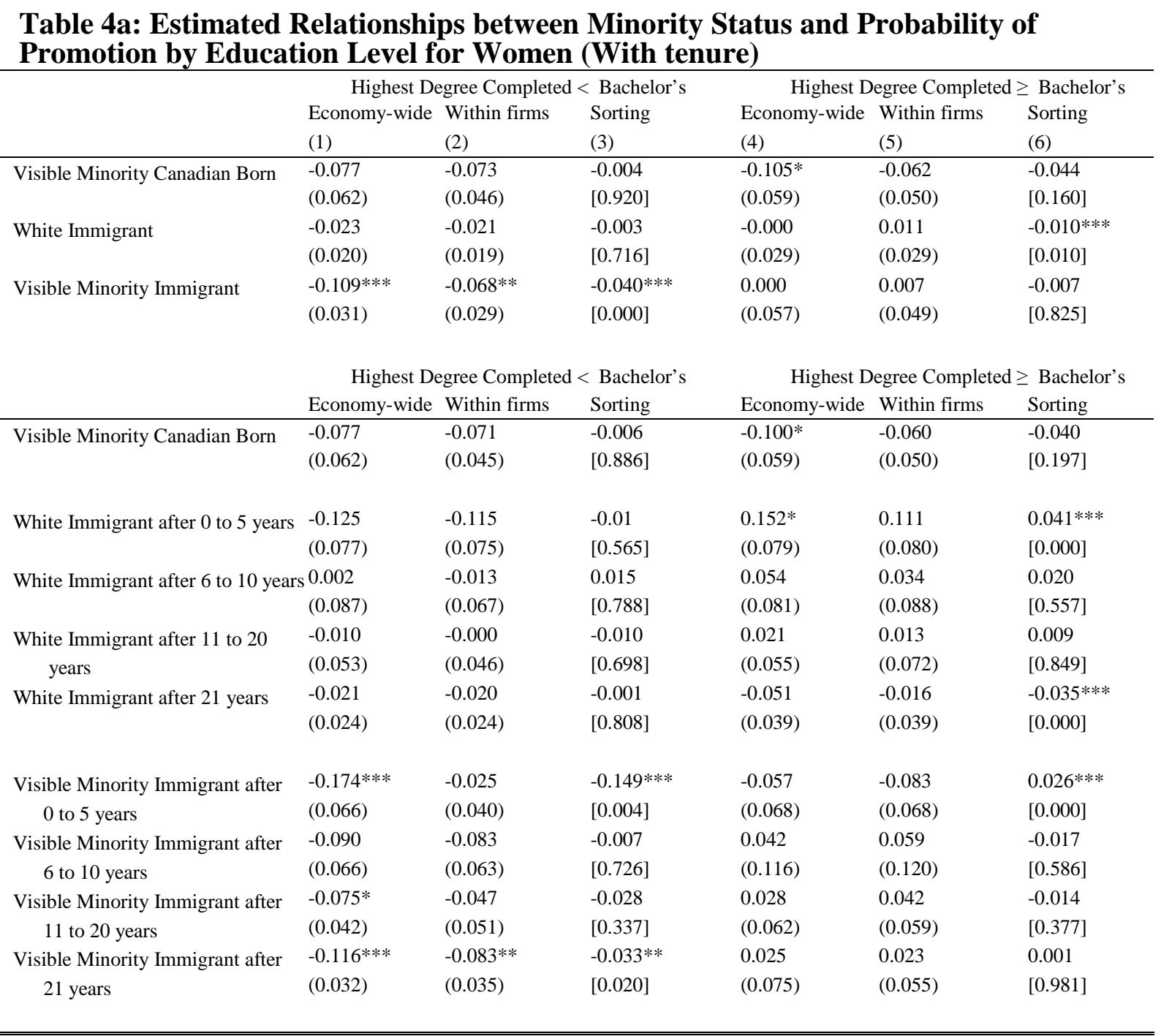

Notes: Standard errors are in parentheses; p-values for the Hausman test of the equality of the economy-wide and within-firm estimates are in brackets. The reference group for all regressions is white Canadian-born. *** indicates statistically significant at $1 \%$, ** indicates statistically significant at $5 \%$, and * indicates statistically significant at $10 \%$. All coefficients are estimated using sampling weights provided by Statistics Canada, and the standard errors are computed using 100 sets of bootstrap weights provided by Statistics Canada. Controls include the personal characteristics, job characteristics, and geography controls detailed in Table 1 (excluding industry and occupation). 


\section{Table 4b: Estimated Relationships between Minority Status and Probability of Promotion by Education Level for Men (With Tenure)}

\begin{tabular}{|c|c|c|c|c|c|c|}
\hline & \multicolumn{3}{|c|}{ Highest Degree Completed $<$ Bachelor's } & \multicolumn{3}{|c|}{ Highest Degree Completed $\geq$ Bachelor's } \\
\hline & $\begin{array}{l}\text { Economy-wide } \\
(1)\end{array}$ & $\begin{array}{l}\text { Within firms } \\
(2)\end{array}$ & $\begin{array}{l}\text { Sorting } \\
\text { (3) }\end{array}$ & $\begin{array}{l}\text { Economy-wide } \\
(4)\end{array}$ & $\begin{array}{l}\text { Within firms } \\
(5)\end{array}$ & $\begin{array}{l}\text { Sorting } \\
(6)\end{array}$ \\
\hline \multirow[t]{2}{*}{ Visible Minority Canadian Born } & -0.075 & -0.082 & 0.008 & -0.093 & $-0.124^{*}$ & $0.031^{* * *}$ \\
\hline & $(0.059)$ & $(0.070)$ & {$[0.835]$} & $(0.068)$ & $(0.069)$ & {$[0.008]$} \\
\hline \multirow[t]{2}{*}{ White Immigrant } & 0.014 & -0.001 & 0.015 & -0.043 & -0.042 & -0.001 \\
\hline & $(0.021)$ & $(0.018)$ & {$[0.156]$} & $(0.032)$ & $(0.030)$ & {$[0.938]$} \\
\hline \multirow[t]{4}{*}{ Visible Minority Immigrant } & -0.038 & -0.043 & 0.006 & $-0.061^{*}$ & $-0.061^{*}$ & 0.001 \\
\hline & $(0.025)$ & $(0.028)$ & {$[0.673]$} & $(0.035)$ & $(0.032)$ & {$[0.962]$} \\
\hline & \multicolumn{3}{|c|}{ Highest Degree Completed $<$ Bachelor's } & \multicolumn{3}{|c|}{ Highest Degree Completed $\geq$ Bachelor's } \\
\hline & Economy-wide & Within firms & Sorting & Economy-wide & Within firms & Sorting \\
\hline \multirow[t]{2}{*}{ Visible Minority Canadian Born } & -0.070 & -0.079 & 0.009 & -0.091 & $-0.122^{*}$ & $0.031 * * *$ \\
\hline & $(0.059)$ & $(0.067)$ & {$[0.784]$} & $(0.067)$ & $(0.068)$ & {$[0.007]$} \\
\hline \multirow[t]{2}{*}{ White Immigrant after 0 to 5 years } & $0.183^{* *}$ & $0.211^{* *}$ & -0.028 & -0.024 & 0.030 & $-0.054 *$ \\
\hline & $(0.087)$ & $(0.084)$ & {$[0.252]$} & $(0.057)$ & $(0.050)$ & {$[0.053]$} \\
\hline \multirow[t]{2}{*}{ White Immigrant after 6 to 10 years } & $0.162 * * *$ & $0.175^{* * *}$ & -0.013 & -0.027 & -0.078 & $0.051^{* * *}$ \\
\hline & $(0.053)$ & $(0.054)$ & [0.304] & $(0.069)$ & $(0.071)$ & {$[0.001]$} \\
\hline \multirow{2}{*}{$\begin{array}{l}\text { White Immigrant after } 11 \text { to } 20 \\
\text { years }\end{array}$} & 0.063 & 0.026 & $0.037 * *$ & -0.006 & -0.010 & 0.004 \\
\hline & $(0.047)$ & $(0.044)$ & [0.037] & $(0.085)$ & $(0.073)$ & [0.918] \\
\hline \multirow[t]{2}{*}{ White Immigrant after 21 years } & -0.017 & -0.032 & 0.015 & -0.054 & -0.047 & -0.007 \\
\hline & $(0.025)$ & $(0.021)$ & [0.261] & $(0.038)$ & (0.039) & [0.463] \\
\hline \multirow{2}{*}{$\begin{array}{l}\text { Visible Minority Immigrant after } \\
0 \text { to } 5 \text { years }\end{array}$} & 0.004 & -0.023 & 0.027 & -0.060 & -0.027 & -0.033 \\
\hline & $(0.074)$ & $(0.092)$ & [0.623] & $(0.055)$ & $(0.063)$ & [0.296] \\
\hline \multirow{2}{*}{$\begin{array}{l}\text { Visible Minority Immigrant after } \\
6 \text { to } 10 \text { years }\end{array}$} & 0.077 & 0.043 & $0.035^{* *}$ & 0.020 & -0.001 & 0.020 \\
\hline & (0.069) & $(0.070)$ & [0.012] & $(0.068)$ & $(0.056)$ & {$[0.600]$} \\
\hline \multirow{2}{*}{$\begin{array}{l}\text { Visible Minority Immigrant after } \\
11 \text { to } 20 \text { years }\end{array}$} & 0.010 & 0.003 & 0.007 & -0.021 & -0.008 & -0.013 \\
\hline & $(0.043)$ & $(0.049)$ & [0.768] & $(0.062)$ & $(0.050)$ & {$[0.717]$} \\
\hline \multirow{2}{*}{$\begin{array}{l}\text { Visible Minority Immigrant after } \\
21 \text { years }\end{array}$} & $-0.093 * * *$ & $-0.073^{* *}$ & -0.021 & $-0.104^{* *}$ & $-0.116 * * *$ & 0.012 \\
\hline & $(0.029)$ & $(0.034)$ & [0.229] & $(0.041)$ & $(0.033)$ & {$[0.630]$} \\
\hline
\end{tabular}

Notes: Standard errors are in parentheses; p-values for the Hausman test of the equality of the economy-wide and within-firm estimates are in brackets. The reference group for all regressions is white Canadian-born. *** indicates statistically significant at $1 \%$, ** indicates statistically significant at 5\%, and * indicates statistically significant at $10 \%$. All coefficients are estimated using sampling weights provided by Statistics Canada, and the standard errors are computed using 100 sets of bootstrap weights provided by Statistics Canada. Controls include the personal characteristics, job characteristics, and geography controls detailed in Table 1 (excluding industry and occupation). 


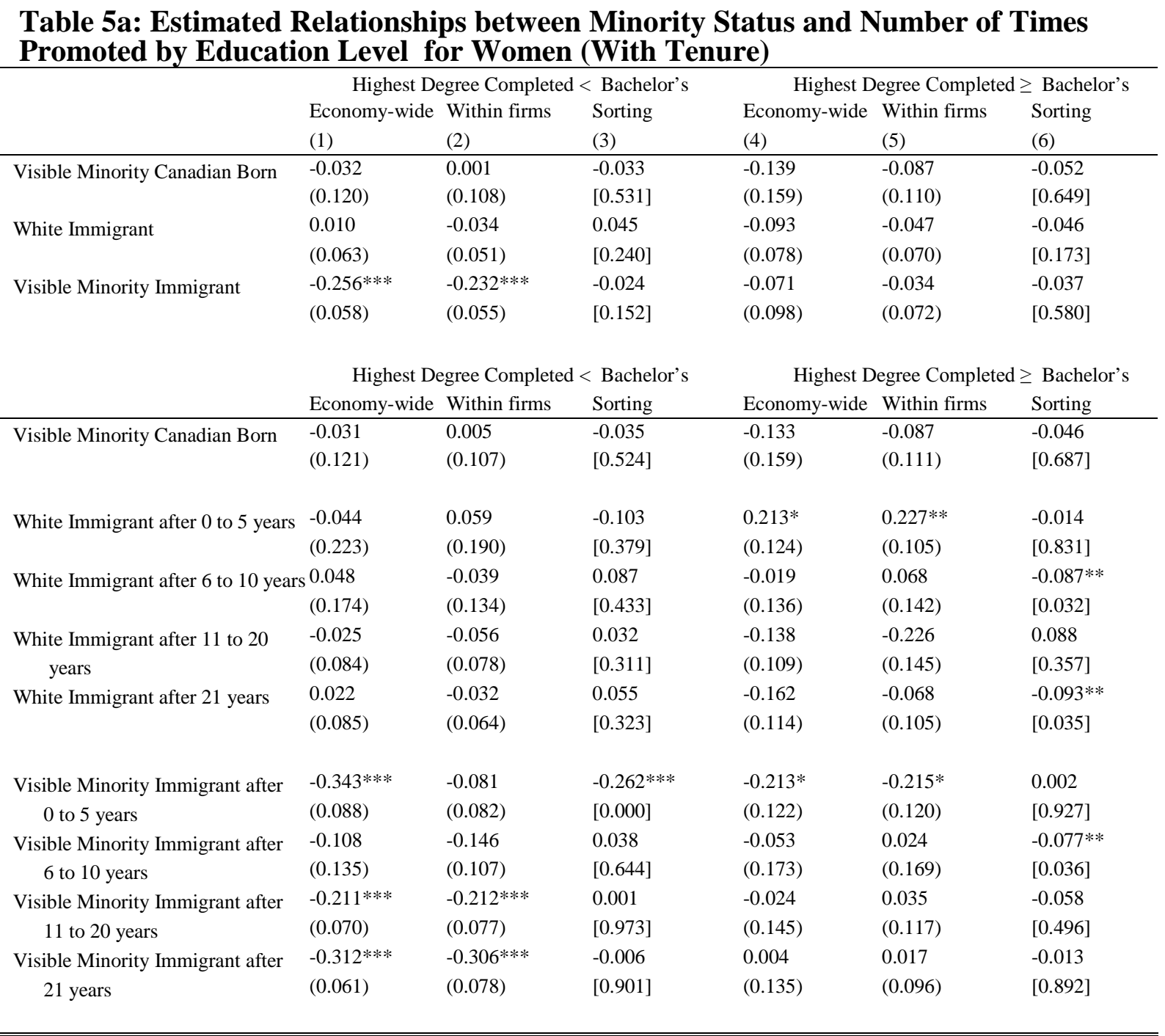

Notes: Standard errors are in parentheses; p-values for the Hausman test of the equality of the economy-wide and within-firm estimates are in brackets. The reference group for all regressions is white Canadian-born. *** indicates statistically significant at $1 \%$, ** indicates statistically significant at $5 \%$, and * indicates statistically significant at $10 \%$. All coefficients are estimated using sampling weights provided by Statistics Canada, and the standard errors are computed using 100 sets of bootstrap weights provided by Statistics Canada. Controls include the personal characteristics, job characteristics, and geography controls detailed in Table 1 (excluding industry and occupation). 


\begin{tabular}{|c|c|c|c|c|c|c|}
\hline \multicolumn{7}{|c|}{$\begin{array}{r}\text { Promoted by Education Level for Men (With tenure } \\
\text { Highest Degree Completed }<\text { Bachelor's }\end{array}$} \\
\hline & $\begin{array}{l}\text { Economy-wide } \\
\text { (1) }\end{array}$ & $\begin{array}{l}\text { Within firms } \\
\text { (2) }\end{array}$ & $\begin{array}{l}\text { Sorting } \\
\text { (3) }\end{array}$ & $\begin{array}{l}\text { Economy-wide } \\
\text { (4) }\end{array}$ & $\begin{array}{l}\text { Within firms } \\
\text { (5) }\end{array}$ & $\begin{array}{l}\text { Sorting } \\
(6)\end{array}$ \\
\hline Visible Minority Canadian Born & $\begin{array}{l}-0.142 \\
(0.174)\end{array}$ & $\begin{array}{l}-0.223 \\
(0.177)\end{array}$ & $\begin{array}{l}0.081^{* *} \\
{[0.012]}\end{array}$ & $\begin{array}{l}-0.449 * * * \\
(0.166)\end{array}$ & $\begin{array}{l}-0.461^{* *} \\
(0.193)\end{array}$ & $\begin{array}{l}0.012 \\
{[0.902]}\end{array}$ \\
\hline White Immigrant & $\begin{array}{l}-0.072 \\
(0.060)\end{array}$ & $\begin{array}{l}-0.068 \\
(0.058)\end{array}$ & $\begin{array}{l}-0.004 \\
{[0.823]}\end{array}$ & $\begin{array}{l}-0.116 \\
(0.103)\end{array}$ & $\begin{array}{l}-0.123 \\
(0.091)\end{array}$ & $\begin{array}{l}0.007 \\
{[0.882]}\end{array}$ \\
\hline Visible Minority Immigrant & $\begin{array}{l}-0.199 * * * \\
(0.066)\end{array}$ & $\begin{array}{l}-0.169 * * \\
(0.085)\end{array}$ & $\begin{array}{l}-0.03 \\
{[0.573]}\end{array}$ & $\begin{array}{l}-0.239 * * \\
(0.095)\end{array}$ & $\begin{array}{l}-0.166^{*} \\
(0.087)\end{array}$ & $\begin{array}{l}-0.073^{*} \\
{[0.051]}\end{array}$ \\
\hline & $\begin{array}{l}\text { Highest De } \\
\text { Economy-wide }\end{array}$ & $\begin{array}{l}\text { gree Completed } \\
\text { Within firms }\end{array}$ & $\begin{array}{l}\text { Bachelor's } \\
\text { Sorting }\end{array}$ & $\begin{array}{l}\text { Highest D } \\
\text { Economy-wide }\end{array}$ & $\begin{array}{l}\text { egree Complet } \\
\text { Within firms }\end{array}$ & $\begin{array}{l}\geq \text { Bachelor's } \\
\text { Sorting }\end{array}$ \\
\hline Visible Minority Canadian Born & $\begin{array}{l}-0.133 \\
(0.174)\end{array}$ & $\begin{array}{l}-0.216 \\
(0.176)\end{array}$ & $\begin{array}{l}0.083^{* * *} \\
{[0.001]}\end{array}$ & $\begin{array}{l}-0.448^{* * *} \\
(0.165)\end{array}$ & $\begin{array}{l}-0.458^{* *} \\
(0.192)\end{array}$ & $\begin{array}{l}0.01 \\
{[0.918]}\end{array}$ \\
\hline White Immigrant after 0 to 5 years & $\begin{array}{l}0.147 \\
(0.129)\end{array}$ & $\begin{array}{l}0.045 \\
(0.171)\end{array}$ & $\begin{array}{l}0.103 \\
{[0.361]}\end{array}$ & $\begin{array}{l}-0.121 \\
(0.104)\end{array}$ & $\begin{array}{l}-0.141 \\
(0.138)\end{array}$ & $\begin{array}{l}0.02 \\
{[0.825]}\end{array}$ \\
\hline White Immigrant after 6 to 10 years & $\begin{array}{l}0.210 \\
(0.128)\end{array}$ & $\begin{array}{l}0.251^{* *} \\
(0.112)\end{array}$ & $\begin{array}{l}-0.041 \\
{[0.508]}\end{array}$ & $\begin{array}{l}-0.154 \\
(0.171)\end{array}$ & $\begin{array}{l}-0.217 \\
(0.177)\end{array}$ & $\begin{array}{l}0.063 \\
{[0.167]}\end{array}$ \\
\hline $\begin{array}{l}\text { White Immigrant after } 11 \text { to } 20 \\
\text { years }\end{array}$ & $\begin{array}{l}0.050 \\
(0.145)\end{array}$ & $\begin{array}{l}-0.021 \\
(0.150)\end{array}$ & $\begin{array}{l}0.071^{*} \\
{[0.064]}\end{array}$ & $\begin{array}{l}-0.110 \\
(0.177)\end{array}$ & $\begin{array}{l}-0.089 \\
(0.182)\end{array}$ & $\begin{array}{l}-0.021 \\
{[0.616]}\end{array}$ \\
\hline White Immigrant after 21 years & $\begin{array}{l}-0.131^{*} \\
(0.067)\end{array}$ & $\begin{array}{l}-0.107^{*} \\
(0.065)\end{array}$ & $\begin{array}{l}-0.024 \\
{[0.169]}\end{array}$ & $\begin{array}{l}-0.096 \\
(0.139)\end{array}$ & $\begin{array}{l}-0.092 \\
(0.121)\end{array}$ & $\begin{array}{l}-0.004 \\
{[0.946]}\end{array}$ \\
\hline $\begin{array}{l}\text { Visible Minority Immigrant after } \\
0 \text { to } 5 \text { years }\end{array}$ & $\begin{array}{l}-0.054 \\
(0.099)\end{array}$ & $\begin{array}{l}-0.179 \\
(0.189)\end{array}$ & $\begin{array}{l}0.125 \\
{[0.439]}\end{array}$ & $\begin{array}{l}-0.274^{* *} \\
(0.110)\end{array}$ & $\begin{array}{l}-0.148 \\
(0.141)\end{array}$ & $\begin{array}{l}-0.126 \\
{[0.153]}\end{array}$ \\
\hline $\begin{array}{l}\text { Visible Minority Immigrant after } \\
6 \text { to } 10 \text { years }\end{array}$ & $\begin{array}{l}0.014 \\
(0.140)\end{array}$ & $\begin{array}{l}0.006 \\
(0.118)\end{array}$ & $\begin{array}{l}0.008 \\
{[0.918]}\end{array}$ & $\begin{array}{l}-0.101 \\
(0.126)\end{array}$ & $\begin{array}{l}-0.080 \\
(0.124)\end{array}$ & $\begin{array}{l}-0.021 \\
{[0.352]}\end{array}$ \\
\hline $\begin{array}{l}\text { Visible Minority Immigrant after } \\
11 \text { to } 20 \text { years }\end{array}$ & $\begin{array}{l}-0.094 \\
(0.111)\end{array}$ & $\begin{array}{l}-0.069 \\
(0.136)\end{array}$ & $\begin{array}{l}-0.024 \\
{[0.757]}\end{array}$ & $\begin{array}{l}-0.158 \\
(0.140)\end{array}$ & $\begin{array}{l}-0.007 \\
(0.125)\end{array}$ & $\begin{array}{l}-0.150 * * \\
{[0.016]}\end{array}$ \\
\hline $\begin{array}{l}\text { Visible Minority Immigrant after } \\
21 \text { years }\end{array}$ & $\begin{array}{l}-0.333^{* * *} \\
(0.072)\end{array}$ & $\begin{array}{l}-0.246^{* * *} \\
(0.091)\end{array}$ & $\begin{array}{l}-0.087 \\
{[0.119]}\end{array}$ & $\begin{array}{l}-0.332 * * \\
(0.135)\end{array}$ & $\begin{array}{l}-0.293^{* * *} \\
(0.112)\end{array}$ & $\begin{array}{l}-0.039 \\
{[0.604]}\end{array}$ \\
\hline
\end{tabular}

Notes: Standard errors are in parentheses; p-values for the Hausman test of the equality of the economy-wide and within-firm estimates are in brackets. The reference group for all regressions is white Canadian-born. *** indicates statistically significant at $1 \%$, ** indicates statistically significant at $5 \%$, and * indicates statistically significant at $10 \%$. All coefficients are estimated using sampling weights provided by Statistics Canada, and the standard errors are computed using 100 sets of bootstrap weights provided by Statistics Canada. Controls include the personal characteristics, job characteristics, and geography controls detailed in Table 1 (excluding industry and occupation). 


\section{Appendix Table 1: Estimated Relationships between Minority Status and}

Probability of Promotion with Alternative Controls

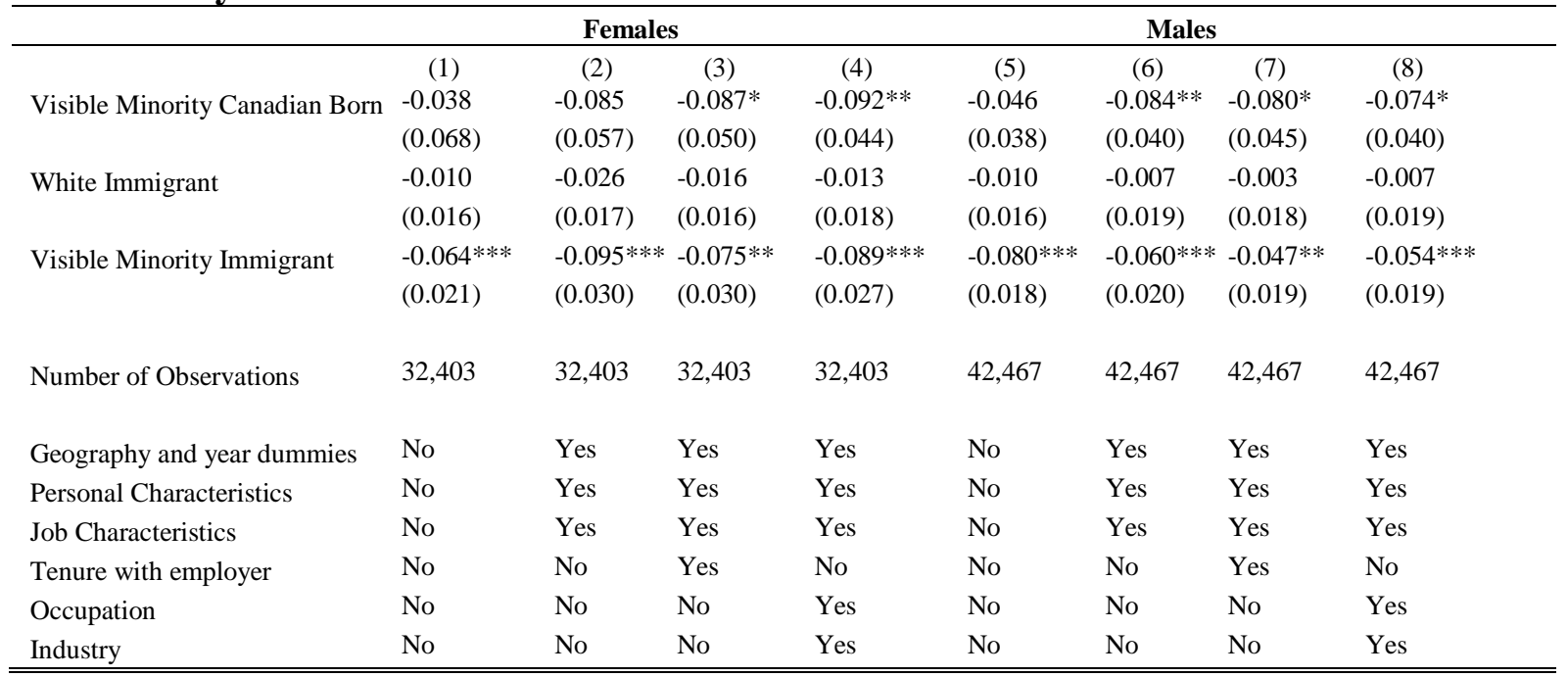

Notes: Standard errors are in parentheses. The reference group for all regressions is white Canadian-born. *** indicates statistically significant at $1 \%$, ** indicates statistically significant at 5\%, and * indicates statistically significant at $10 \%$. All coefficients are estimated using sampling weights provided by Statistics Canada and all the standard errors are computed using 100 sets of bootstrap weights provided by Statistics Canada. Controls refer to the personal characteristics, job characteristics, and geography controls detailed in Table 1 . 


\begin{tabular}{|c|c|c|c|c|c|c|}
\hline & \multicolumn{3}{|c|}{ Highest Degree Completed $<$ Bachelor's } & \multicolumn{3}{|c|}{ Highest Degree Completed $\geq$ Bachelor's } \\
\hline & $\begin{array}{l}\text { Economy-wide } \\
\text { (1) }\end{array}$ & $\begin{array}{l}\text { Within firms } \\
\text { (2) }\end{array}$ & $\begin{array}{l}\text { Sorting } \\
\text { (3) }\end{array}$ & $\begin{array}{l}\text { Economy-wide } \\
\text { (4) }\end{array}$ & $\begin{array}{l}\text { Within firms } \\
\text { (5) }\end{array}$ & $\begin{array}{l}\text { Sorting } \\
\text { (6) }\end{array}$ \\
\hline Visible Minority Canadian Born & $\begin{array}{l}-0.068 \\
(0.072)\end{array}$ & $\begin{array}{l}-0.064 \\
(0.050)\end{array}$ & $\begin{array}{l}-0.004 \\
{[0.944]}\end{array}$ & $\begin{array}{l}-0.123^{* *} \\
(0.058)\end{array}$ & $\begin{array}{l}-0.069 \\
(0.053)\end{array}$ & $\begin{array}{l}-0.053 * * \\
{[0.029]}\end{array}$ \\
\hline White Immigrant & $\begin{array}{l}-0.034 \\
(0.021)\end{array}$ & $\begin{array}{l}-0.032 \\
(0.020)\end{array}$ & $\begin{array}{l}-0.002 \\
{[0.690]}\end{array}$ & $\begin{array}{l}-0.010 \\
(0.033)\end{array}$ & $\begin{array}{l}-0.001 \\
(0.033)\end{array}$ & $\begin{array}{l}-0.009 \\
{[0.221]}\end{array}$ \\
\hline Visible Minority Immigrant & $\begin{array}{l}-0.122 * * * \\
(0.033)\end{array}$ & $\begin{array}{l}-0.083^{* * *} \\
(0.030)\end{array}$ & $\begin{array}{l}-0.039 * * * \\
{[0.001]}\end{array}$ & $\begin{array}{l}-0.033 \\
(0.056)\end{array}$ & $\begin{array}{l}-0.028 \\
(0.049)\end{array}$ & $\begin{array}{l}-0.005 \\
{[0.865]}\end{array}$ \\
\hline & \multicolumn{3}{|c|}{ Highest Degree Completed $<$ Bachelor's } & \multicolumn{3}{|c|}{ Highest Degree Completed $\geq$ Bachelor's } \\
\hline & Economy-wide & Within firms & Sorting & Economy-wide & Within firms & Sorting \\
\hline Visible Minority Canadian Born & $\begin{array}{l}-0.070 \\
(0.071)\end{array}$ & $\begin{array}{l}-0.063 \\
(0.049)\end{array}$ & $\begin{array}{l}-0.006 \\
{[0.904]}\end{array}$ & $\begin{array}{l}-0.123^{* *} \\
(0.058)\end{array}$ & $\begin{array}{l}-0.069 \\
(0.053)\end{array}$ & $\begin{array}{l}-0.053^{* *} \\
{[0.026]}\end{array}$ \\
\hline White Immigrant after 0 to 5 years & $\begin{array}{l}-0.218^{* * *} \\
(0.070)\end{array}$ & $\begin{array}{l}-0.199 * * * \\
(0.072)\end{array}$ & $\begin{array}{l}-0.019 \\
{[0.221]}\end{array}$ & $\begin{array}{l}0.065 \\
(0.083)\end{array}$ & $\begin{array}{l}0.053 \\
(0.081)\end{array}$ & $\begin{array}{l}0.011 \\
{[0.500]}\end{array}$ \\
\hline White Immigrant after 6 to 10 years & $\begin{array}{l}-0.036 \\
(0.092)\end{array}$ & $\begin{array}{l}-0.062 \\
(0.068)\end{array}$ & $\begin{array}{l}0.027 \\
{[0.666]}\end{array}$ & $\begin{array}{l}-0.045 \\
(0.081)\end{array}$ & $\begin{array}{l}-0.046 \\
(0.090)\end{array}$ & $\begin{array}{l}0.001 \\
{[0.979]}\end{array}$ \\
\hline $\begin{array}{l}\text { White Immigrant after } 11 \text { to } 20 \\
\text { years }\end{array}$ & $\begin{array}{l}-0.051 \\
(0.051)\end{array}$ & $\begin{array}{l}-0.039 \\
(0.044)\end{array}$ & $\begin{array}{l}-0.012 \\
{[0.642]}\end{array}$ & $\begin{array}{l}0.014 \\
(0.057)\end{array}$ & $\begin{array}{l}0.007 \\
(0.076)\end{array}$ & $\begin{array}{l}0.007 \\
{[0.889]}\end{array}$ \\
\hline White Immigrant after 21 years & $\begin{array}{l}-0.018 \\
(0.026)\end{array}$ & $\begin{array}{l}-0.017 \\
(0.026)\end{array}$ & $\begin{array}{l}-0.002 \\
{[0.506]}\end{array}$ & $\begin{array}{l}-0.032 \\
(0.044)\end{array}$ & $\begin{array}{l}-0.009 \\
(0.044)\end{array}$ & $\begin{array}{l}-0.023 * * * \\
{[0.000]}\end{array}$ \\
\hline $\begin{array}{l}\text { Visible Minority Immigrant after } \\
0 \text { to } 5 \text { years }\end{array}$ & $\begin{array}{l}-0.222 * * * \\
(0.066)\end{array}$ & $\begin{array}{l}-0.084^{* *} \\
(0.042)\end{array}$ & $\begin{array}{l}-0.138^{* * *} \\
{[0.006]}\end{array}$ & $\begin{array}{l}-0.166^{* *} \\
(0.070)\end{array}$ & $\begin{array}{l}-0.187 * * * \\
(0.069)\end{array}$ & $\begin{array}{l}0.021 \\
{[0.171]}\end{array}$ \\
\hline $\begin{array}{l}\text { Visible Minority Immigrant after } \\
6 \text { to } 10 \text { years }\end{array}$ & $\begin{array}{l}-0.134^{* *} \\
(0.067)\end{array}$ & $\begin{array}{l}-0.129 * * \\
(0.063)\end{array}$ & $\begin{array}{l}-0.005 \\
{[0.817]}\end{array}$ & $\begin{array}{l}0.013 \\
(0.116)\end{array}$ & $\begin{array}{l}0.032 \\
(0.119)\end{array}$ & $\begin{array}{l}-0.019 \\
{[0.478]}\end{array}$ \\
\hline $\begin{array}{l}\text { Visible Minority Immigrant after } \\
11 \text { to } 20 \text { years }\end{array}$ & $\begin{array}{l}-0.089 * * \\
(0.044)\end{array}$ & $\begin{array}{l}-0.053 \\
(0.052)\end{array}$ & $\begin{array}{l}-0.036 \\
{[0.177]}\end{array}$ & $\begin{array}{l}0.004 \\
(0.063)\end{array}$ & $\begin{array}{l}0.010 \\
(0.059)\end{array}$ & $\begin{array}{l}-0.006 \\
{[0.770]}\end{array}$ \\
\hline $\begin{array}{l}\text { Visible Minority Immigrant after } \\
21 \text { years }\end{array}$ & $\begin{array}{l}-0.115^{* * *} \\
(0.034)\end{array}$ & $\begin{array}{l}-0.087 * * \\
(0.037)\end{array}$ & $\begin{array}{l}-0.028 * * \\
{[0.040]}\end{array}$ & $\begin{array}{l}-0.002 \\
(0.075)\end{array}$ & $\begin{array}{l}0.004 \\
(0.057)\end{array}$ & $\begin{array}{l}-0.007 \\
{[0.891]}\end{array}$ \\
\hline
\end{tabular}

Notes: Standard errors are in parentheses; p-values for the Hausman test of the equality of the economy-wide and within-firm estimates are in brackets. The reference group for all regressions is white Canadian-born. *** indicates statistically significant at $1 \%$, ** indicates statistically significant at $5 \%$, and $*$ indicates statistically significant at $10 \%$. All coefficients are estimated using sampling weights provided by Statistics Canada, and the standard errors are computed using 100 sets of bootstrap weights provided by Statistics Canada. Controls include the personal characteristics, job characteristics, and geography controls detailed in Table 1 (excluding industry and occupation). 


\section{Appendix Table 2b: Estimated Relationships between Minority Status and Probability Promotion by Education Level for Men (Without Tenure)}

$$
\text { (1) }
$$

Highest Degree Completed < Bachelor’s

Economy-wide Within firms Sorting

\begin{tabular}{lllllll} 
& $(1)$ & $(2)$ & $(3)$ & $(4)$ & $(5)$ & $(6)$ \\
\hline Visible Minority Canadian Born & $-0.089^{*}$ & -0.086 & -0.004 & -0.062 & -0.104 & $0.042^{* * *}$ \\
& $(0.052)$ & $(0.062)$ & {$[0.911]$} & $(0.068)$ & $(0.066)$ & {$[0.010]$} \\
White Immigrant & 0.015 & 0.001 & 0.013 & $-0.067 * *$ & $-0.070^{* *}$ & 0.003 \\
& $(0.022)$ & $(0.018)$ & {$[0.276]$} & $(0.034)$ & $(0.031)$ & {$[0.821]$} \\
Visible Minority Immigrant & $-0.047^{*}$ & -0.043 & -0.004 & $-0.082^{* *}$ & $-0.070^{* *}$ & -0.011 \\
& $(0.025)$ & $(0.029)$ & {$[0.764]$} & $(0.037)$ & $(0.032)$ & {$[0.540]$}
\end{tabular}

Highest Degree Completed $<$ Bachelor’s

Economy-wide Within firms Sorting

Visible Minority Canadian Born
White Immigrant after 0 to 5 years
White Immigrant after 6 to 10 years
White Immigrant after 11 to 20
years
White Immigrant after 21 years
Visible Minority Immigrant after
0 to 5 years
Visible Minority Immigrant after
6 to 10 years
Visible Minority Immigrant after
11 to 20 years
Visible Minority Immigrant after
21 years

$\begin{array}{ll}-0.083 & -0.004 \\ (0.061) & {[0.903]} \\ & \\ 0.136 & -0.059\end{array}$

\subsection{7}

(0.077)

0.105*

(0.064)

0.062

(0.049)

$-0.008$

(0.026)

$-0.094$

$(0.079)$

0.021

$(0.067)$

0.005

(0.045)

$-0.078^{* * *}$

(0.029)

\section{(0.090)}

[0.213]

$0.136 *$

(0.071)

0.011

(0.048)

$-0.019$

$(0.021)$

$-0.092$

(0.094)

$-0.008$

$(0.073)$

0.008

(0.052)

$-0.056 *$

(0.033)
$-0.031$

[0.301]

$0.051^{* * *}$

[0.000]

0.012

[0.423]

\section{$-0.002$}

[0.967]

0.029

[0.323]

$-0.003$

[0.895]

$-0.023$

[0.181]
(2)

Highest Degree Completed $\geq$ Bachelor's Economy-wide Within firms Sorting

Highest Degree Completed $\geq$ Bachelor's Economy-wide Within firms Sorting

$\begin{array}{lll}-0.064 & -0.105 & 0.041^{* *} \\ (0.068) & (0.065) & {[0.037]} \\ & & \\ -0.130^{*} & -0.072 & -0.059 \\ (0.069) & (0.053) & {[0.166]} \\ -0.079 & -0.121^{*} & 0.043^{*} \\ (0.068) & (0.072) & {[0.067]} \\ -0.062 & -0.060 & -0.002 \\ (0.074) & (0.064) & {[0.958]} \\ -0.055 & -0.060 & 0.006 \\ (0.041) & (0.039) & {[0.499]} \\ & & \\ -0.205 * * * & -0.142^{* *} & -0.063 * * * \\ (0.057) & (0.062) & {[0.010]} \\ -0.051 & -0.053 & 0.002 \\ (0.069) & (0.054) & {[0.972]} \\ -0.037 & 0.001 & -0.038 \\ (0.062) & (0.049) & {[0.318]} \\ -0.074 & -0.091^{* *} & 0.017 \\ (0.045) & (0.037) & {[0.510]}\end{array}$

Notes: Standard errors are in parentheses; p-values for the Hausman test of the equality of the economy-wide and within-firm estimates are in brackets. The reference group for all regressions is white Canadian-born. *** indicates statistically significant at $1 \%$, ** indicates statistically significant at $5 \%$, and * indicates statistically significant at $10 \%$. All coefficients are estimated using sampling weights provided by Statistics Canada, and the standard errors are computed using 100 sets of bootstrap weights provided by Statistics Canada. Controls include the personal characteristics, job characteristics, and geography controls detailed in Table 1 (excluding industry and occupation). 


\section{Appendix Table 3a: Estimated Relationships between Minority Status and Number of Times Promoted by Education Level for Women (Without Tenure)}

\begin{tabular}{|c|c|c|c|c|c|c|}
\hline & \multicolumn{3}{|c|}{ Highest Degree Completed $<$ Bachelor's } & \multicolumn{3}{|c|}{ Highest Degree Completed $\geq$ Bachelor's } \\
\hline & $\begin{array}{l}\text { Economy-wide } \\
\text { (1) }\end{array}$ & $\begin{array}{l}\text { Within firms } \\
(2)\end{array}$ & $\begin{array}{l}\text { Sorting } \\
\text { (3) }\end{array}$ & $\begin{array}{l}\text { Economy-wide } \\
\text { (4) }\end{array}$ & $\begin{array}{l}\text { Within firms } \\
\text { (5) }\end{array}$ & $\begin{array}{l}\text { Sorting } \\
(6)\end{array}$ \\
\hline \multirow[t]{2}{*}{ Visible Minority Canadian Born } & -0.006 & 0.028 & -0.034 & -0.198 & -0.111 & -0.087 \\
\hline & $(0.145)$ & $(0.122)$ & {$[0.661]$} & $(0.160)$ & $(0.124)$ & {$[0.389]$} \\
\hline \multirow[t]{2}{*}{ White Immigrant } & -0.024 & -0.064 & 0.040 & -0.137 & -0.100 & -0.037 \\
\hline & $(0.067)$ & $(0.054)$ & {$[0.321]$} & $(0.088)$ & $(0.082)$ & {$[0.237]$} \\
\hline \multirow[t]{4}{*}{ Visible Minority Immigrant } & $-0.301 * * *$ & $-0.271 * * *$ & -0.03 & $-0.186 *$ & $-0.148 *$ & -0.038 \\
\hline & $(0.063)$ & $(0.059)$ & {$[0.163]$} & $(0.100)$ & $(0.077)$ & {$[0.548]$} \\
\hline & \multicolumn{3}{|c|}{ Highest Degree Completed < Bachelor's } & \multicolumn{3}{|c|}{ Highest Degree Completed $\geq$ Bachelor's } \\
\hline & Economy-wide & Within firms & Sorting & Economy-wide & Within firms & Sorting \\
\hline \multirow[t]{2}{*}{ Visible Minority Canadian Born } & -0.010 & 0.030 & -0.040 & -0.209 & -0.118 & -0.091 \\
\hline & $(0.144)$ & $(0.121)$ & {$[0.606]$} & $(0.159)$ & $(0.124)$ & {$[0.36]$} \\
\hline \multirow[t]{2}{*}{ White Immigrant after 0 to 5 years } & -0.308 & -0.158 & -0.15 & -0.071 & 0.036 & -0.107 \\
\hline & $(0.202)$ & $(0.173)$ & {$[0.150]$} & $(0.134)$ & $(0.112)$ & {$[0.145]$} \\
\hline \multirow[t]{2}{*}{ White Immigrant after 6 to 10 years } & -0.077 & -0.182 & 0.105 & $-0.359 * *$ & -0.210 & $-0.149 * * *$ \\
\hline & $(0.195)$ & $(0.136)$ & {$[0.453]$} & $(0.141)$ & $(0.143)$ & {$[0.000]$} \\
\hline \multirow{2}{*}{$\begin{array}{l}\text { White Immigrant after } 11 \text { to } 20 \\
\text { years }\end{array}$} & $-0.165^{* *}$ & $-0.176^{* *}$ & 0.011 & $-0.186^{*}$ & $-0.271^{*}$ & 0.085 \\
\hline & $(0.082)$ & $(0.078)$ & {$[0.668]$} & $(0.113)$ & $(0.163)$ & {$[0.469]$} \\
\hline \multirow[t]{2}{*}{ White Immigrant after 21 years } & 0.029 & -0.024 & 0.053 & -0.112 & -0.061 & -0.051 \\
\hline & $(0.091)$ & $(0.069)$ & {$[0.367]$} & $(0.127)$ & $(0.118)$ & {$[0.281]$} \\
\hline Visible Minority Immigrant after & $-0.475 * * *$ & $-0.229 * *$ & $-0.246^{* * *}$ & $-0.571 * * *$ & $-0.540 * * *$ & -0.031 \\
\hline 0 to 5 years & $(0.090)$ & $(0.089)$ & {$[0.000]$} & $(0.138)$ & $(0.132)$ & {$[0.441]$} \\
\hline Visible Minority Immigrant after & $-0.250^{*}$ & $-0.270 * *$ & 0.02 & -0.151 & -0.063 & $-0.088 *$ \\
\hline 6 to 10 years & $(0.133)$ & $(0.110)$ & {$[0.789]$} & $(0.194)$ & $(0.188)$ & {$[0.066]$} \\
\hline Visible Minority Immigrant after & $-0.271^{* * *}$ & $-0.235 * * *$ & $-0.036 * * *$ & -0.116 & -0.084 & -0.031 \\
\hline 11 to 20 years & $(0.080)$ & $(0.081)$ & {$[0.002]$} & $(0.165)$ & $(0.129)$ & {$[0.758]$} \\
\hline Visible Minority Immigrant after & $-0.311 * * *$ & $-0.316^{* * *}$ & 0.005 & -0.092 & -0.050 & -0.042 \\
\hline 21 years & $(0.067)$ & $(0.085)$ & [0.923] & $(0.135)$ & $(0.108)$ & [0.603] \\
\hline
\end{tabular}

Notes: Standard errors are in parentheses; p-values for the Hausman test of the equality of the economy-wide and within-firm estimates are in brackets. The reference group for all regressions is white Canadian-born. *** indicates statistically significant at $1 \%$, ** indicates statistically significant at $5 \%$, and $*$ indicates statistically significant at $10 \%$. All coefficients are estimated using sampling weights provided by Statistics Canada, and the standard errors are computed using 100 sets of bootstrap weights provided by Statistics Canada. Controls include the personal characteristics, job characteristics, and geography controls detailed in Table 1 (excluding industry and occupation). 


\section{Appendix Table 3b: Estimated Relationships between Minority Status and Number of Times Promoted by Education Level for Men (Without tenure)}

\begin{tabular}{|c|c|c|c|c|c|c|}
\hline & \multicolumn{3}{|c|}{ Highest Degree Completed $<$ Bachelor's } & \multicolumn{3}{|c|}{ Highest Degree Completed $\geq$ Bachelor's } \\
\hline & $\begin{array}{l}\text { Economy-wide } \\
\text { (1) }\end{array}$ & $\begin{array}{l}\text { Within firms } \\
\text { (2) }\end{array}$ & $\begin{array}{l}\text { Sorting } \\
\text { (3) }\end{array}$ & $\begin{array}{l}\text { Economy-wide } \\
\text { (4) }\end{array}$ & $\begin{array}{l}\text { Within firms } \\
\text { (5) }\end{array}$ & $\begin{array}{l}\text { Sorting } \\
(6)\end{array}$ \\
\hline \multirow[t]{2}{*}{ Visible Minority Canadian Born } & -0.199 & -0.237 & 0.038 & $-0.351^{* *}$ & $-0.422 * *$ & 0.071 \\
\hline & $(0.152)$ & $(0.163)$ & {$[0.518]$} & $(0.165)$ & $(0.189)$ & {$[0.441]$} \\
\hline \multirow[t]{2}{*}{ White Immigrant } & -0.085 & -0.066 & -0.018 & $-0.231^{* *}$ & $-0.251^{* * *}$ & 0.02 \\
\hline & $(0.060)$ & $(0.055)$ & {$[0.438]$} & $(0.110)$ & $(0.086)$ & {$[0.769]$} \\
\hline \multirow{4}{*}{ Visible Minority Immigrant } & $-0.235^{* * *}$ & $-0.159 *$ & -0.076 & $-0.342 * * *$ & $-0.207 * *$ & $-0.135^{* *}$ \\
\hline & $(0.064)$ & $(0.087)$ & {$[0.198]$} & $(0.108)$ & $(0.092)$ & {$[0.016]$} \\
\hline & \multicolumn{3}{|c|}{ Highest Degree Completed < Bachelor's } & \multicolumn{3}{|c|}{ Highest Degree Completed $\geq$ Bachelor's } \\
\hline & Economy-wide & Within firms & Sorting & Economy-wide & Within firms & Sorting \\
\hline \multirow[t]{2}{*}{ Visible Minority Canadian Born } & -0.198 & -0.236 & 0.038 & $-0.370 * *$ & $-0.431^{* *}$ & 0.061 \\
\hline & $(0.151)$ & $(0.164)$ & {$[0.552]$} & $(0.165)$ & $(0.188)$ & {$[0.498]$} \\
\hline \multirow[t]{2}{*}{ White Immigrant after 0 to 5 years } & -0.212 & -0.209 & -0.003 & $-0.532 * * *$ & $-0.510 * * *$ & -0.022 \\
\hline & $(0.132)$ & $(0.199)$ & {$[0.983]$} & $(0.140)$ & $(0.170)$ & {$[0.819]$} \\
\hline \multirow[t]{2}{*}{ White Immigrant after 6 to 10 years } & -0.009 & 0.116 & -0.124 & $-0.399 * *$ & $-0.415^{* *}$ & 0.016 \\
\hline & $(0.163)$ & $(0.141)$ & {$[0.127]$} & $(0.180)$ & $(0.185)$ & {$[0.708]$} \\
\hline \multirow{2}{*}{$\begin{array}{l}\text { White Immigrant after } 11 \text { to } 20 \\
\text { years }\end{array}$} & 0.020 & -0.087 & $0.107 * *$ & $-0.395^{* *}$ & $-0.330 * *$ & -0.065 \\
\hline & $(0.157)$ & $(0.163)$ & {$[0.014]$} & $(0.157)$ & $(0.165)$ & {$[0.200]$} \\
\hline \multirow[t]{2}{*}{ White Immigrant after 21 years } & -0.111 & -0.070 & -0.041 & -0.110 & -0.157 & 0.047 \\
\hline & $(0.068)$ & $(0.063)$ & {$[0.115]$} & $(0.145)$ & $(0.109)$ & {$[0.623]$} \\
\hline Visible Minority Immigrant after & $-0.373 * * *$ & $-0.377 *$ & 0.004 & $-0.798 * * *$ & $-0.509 * * *$ & $-0.289 * * *$ \\
\hline 0 to 5 years & $(0.114)$ & $(0.204)$ & {$[0.981]$} & $(0.124)$ & $(0.149)$ & {$[0.000]$} \\
\hline Visible Minority Immigrant after & -0.192 & -0.159 & -0.033 & $-0.411 * * *$ & $-0.290 * *$ & $-0.121 * * *$ \\
\hline 6 to 10 years & $(0.130)$ & $(0.124)$ & {$[0.397]$} & $(0.134)$ & $(0.135)$ & {$[0.000]$} \\
\hline Visible Minority Immigrant after & -0.127 & -0.053 & -0.074 & $-0.294^{*}$ & -0.032 & $-0.261 * * *$ \\
\hline 11 to 20 years & $(0.112)$ & $(0.138)$ & {$[0.358]$} & $(0.168)$ & $(0.138)$ & {$[0.006]$} \\
\hline Visible Minority Immigrant after & $-0.281 * * *$ & $-0.177^{*}$ & $-0.104^{*}$ & -0.232 & -0.206 & -0.026 \\
\hline 21 years & $(0.075)$ & $(0.094)$ & {$[0.070]$} & $(0.147)$ & $(0.126)$ & {$[0.731]$} \\
\hline
\end{tabular}

Notes: Standard errors are in parentheses; p-values for the Hausman test of the equality of the economy-wide and within-firm estimates are in brackets. The reference group for all regressions is white Canadian-born. *** indicates statistically significant at $1 \%$, ** indicates statistically significant at $5 \%$, and * indicates statistically significant at $10 \%$. All coefficients are estimated using sampling weights provided by Statistics Canada, and the standard errors are computed using 100 sets of bootstrap weights provided by Statistics Canada. Controls include the personal characteristics, job characteristics, and geography controls detailed in Table 1 (excluding industry and occupation). 